\title{
Combined Active Humoral and Cellular Immunization Approaches for the Treatment of Synucleinopathies
}

\author{
Edward Rockenstein, ${ }^{1}$ Gary Ostroff, ${ }^{2}$ Fusun Dikengil, ${ }^{2}$ Florentina Rus, ${ }^{2}$ Michael Mante, ${ }^{1}$ - Jazmin Florio, ${ }^{1}$ \\ Anthony Adame, ${ }^{1}$ - Ivy Trinh, ${ }^{1}$ Changyoun Kim, ${ }^{1,3}$ Cassia Overk, ${ }^{1}$ Eliezer Masliah, ${ }^{1,3}$ and $\odot$ Robert A. Rissman ${ }^{1,4}$ \\ ${ }^{1}$ Department of Neurosciences, University of California, San Diego, La Jolla, California 92093-0624, ${ }^{2}$ University of Mass Massachusetts Medical School, \\ Program in Molecular Medicine Worcester, Massachusetts 01605, ${ }^{3}$ Molecular Neuropathology Section, Laboratory of Neurogenetics, National Institute on \\ Aging, National Institutes of Health, Bethesda, Maryland 20892, and ${ }^{4}$ Veterans Affairs San Diego Healthcare System, La Jolla, California 92161
}

Dementia with Lewy bodies, Parkinson's disease, and Multiple System Atrophy are age-related neurodegenerative disorders characterized by progressive accumulation of $\alpha$-synuclein ( $\alpha$-syn) and jointly termed synucleinopathies. Currently, no disease-modifying treatments are available for these disorders. Previous preclinical studies demonstrate that active and passive immunizations targeting $\alpha$-syn partially ameliorate behavioral deficits and $\alpha$-syn accumulation; however, it is unknown whether combining humoral and cellular immunization might act synergistically to reduce inflammation and improve microglial-mediated $\alpha$-syn clearance. Since combined delivery of antigen plus rapamycin (RAP) in nanoparticles is known to induce antigen-specific regulatory T cells (Tregs), we adapted this approach to $\alpha$-syn using the antigen-presenting cell-targeting glucan microparticle (GP) vaccine delivery system. PDGF- $\alpha$-syn transgenic (tg) male and female mice were immunized with GP-alone, GP- $\alpha$-syn (active humoral immunization), GP $+\mathrm{RAP}$, or GP $+\mathrm{RAP} / \alpha$-syn (combined active humoral and Treg) and analyzed using neuropathological and biochemical markers. Active immunization resulted in higher serological total IgG, IgG1, and IgG2a anti- $\alpha$-syn levels. Compared with mice immunized with GP-alone or GP- $\alpha$-syn, mice vaccinated with GP $+\mathrm{RAP}$ or GP $+\mathrm{RAP} / \alpha$-syn displayed increased numbers of CD25-, FoxP3-, and CD4-positive cells in the CNS. GP- $\alpha$-syn or GP+RAP/ $\alpha$-syn immunizations resulted in a 30-45\% reduction in $\alpha$-syn accumulation, neuroinflammation, and neurodegeneration. Mice immunized with GP $+\mathrm{RAP} / \alpha$-syn further rescued neurons and reduced neuroinflammation. Levels of TGF- $\beta 1$ were increased with GP + RAP/ $\alpha$-syn immunization, while levels of TNF- $\alpha$ and IL- 6 were reduced. We conclude that the observed effects of $\mathrm{GP}+\mathrm{RAP} / \alpha$-syn immunization support the hypothesis that cellular immunization may enhance the effects of active immunotherapy for the treatment of synucleinopathies.

Key words: $\alpha$-synuclein; immunization; vaccine; synucleinopathy; Treg; lewy body

Significance Statement

We show that a novel vaccination modality combining an antigen-presenting cell-targeting glucan particle (GP) vaccine delivery system with encapsulated antigen ( $\alpha$-synuclein) + rapamycin (RAP) induced both strong anti- $\alpha$-synuclein antibody titers and regulatory T cells (Tregs). This vaccine, collectively termed GP+RAP/ $\alpha$-syn, is capable of triggering neuroprotective Treg responses in synucleinopathy models, and the combined vaccine is more effective than the humoral or cellular immunization alone. Together, these results support the further development of this multifunctional vaccine approach for the treatment of synucleinopathies, such as Parkinson's disease, dementia with Lewy bodies, and multiple systems atrophy.

\section{Introduction}

Immunotherapy approaches for the management of neurodegenerative disorders other than Alzheimer's disease (AD) have

\section{Received April 6, 2017; revised Dec. 4, 2017; accepted Dec. 6, 2017}

Author contributions: R.A.R., G.O., and E.M. designed research; R.A.R., E.R., G.O., F.D., F.R., M.M., J.F., A.A., I.T., C.K., and E.M. performed research; R.A.R., F.D., F.R., C.O., E.M., and R.A.R. analyzed data; R.A.R., G.O., and E.M. wrote the paper.

This work was funded by National Institutes of Health Grants AG-18840, NS-044233, BX-003040, AG-051839, and AG-10483.

The funding sources had no role in study design; in the collection, analysis and interpretation of data; in the writing of the report; or in the decision to submit the article for publication. The authors declare no competing financial interests. gained considerable interest (Brody and Holtzman, 2008; Valera et al., 2016). In addition, preclinical and clinical trials are underway to test the safety and efficacy of antibodies for the treatment of synucleinopathies (Masliah et al., 2011; Lee and Lee, 2016; Valera and Masliah, 2016a) and tauopathies (Sigurdsson, 2008; Ubhi and Masliah, 2013; Iqbal et al., 2016). Parkinson's disease (PD), dementia with Lewy bodies (DLB), and Multiple System Atrophy. These are neurodegenerative disorders of the aging

Correspondence should be addressed to Robert A. Rissman, Department of Neurosciences, University of California, San Diego, La Jolla, CA 92093-0624. E-mail: rrissman@ucsd.edu. D0I:10.1523/JNEUROSCI.1170-17.2017

Copyright $\odot 2018$ the authors $\quad 0270-6474 / 18 / 381000-15 \$ 15.00 / 0$ 
population pathologically characterized by progressive accumulation of $\alpha$-synuclein ( $\alpha$-syn) and clinically manifested by fluctuating cognitive impairment, parkinsonism, and dysautonomia (McKeith, 2006; Wenning et al., 2008). For these synucleinopathies (Dickson et al., 1999; Spillantini and Goedert, 2000; Galvin et al., 2001), no disease-modifying treatments are currently available. Progressive accumulation of $\alpha$-syn in cortical and subcortical brain regions is assumed to lead to neurodegeneration by interfering with synaptic, mitochondrial, and lysosomal function (Wong and Krainc, 2017). Clinically, PD is characterized by motor deficits including bradykinesia, tremor, rigidity, and postural instability (Jankovic, 2008), along with behavioral alterations, cognitive impairment, sleep disorders, olfactory deficits, and gastrointestinal dysfunction (Savica et al., 2013).

Several experimental strategies were directed at reducing $\alpha$-syn levels, including decreasing the expression of $\alpha$-syn with antisense oligonucleotides (Murphy et al., 2000) or miRNA (Junn et al., 2009), decreasing $\alpha$-syn aggregation with small molecules (Wrasidlo et al., 2016), increasing the clearance of $\alpha$-syn via autophagy (Sarkar and Rubinsztein, 2008), and preventing the seeding and prion-like spreading of $\alpha$-syn (Lashuel et al., 2013; Valera and Masliah, 2016b).

Immunotherapeutic approaches targeting $\alpha$-syn have the advantage of addressing several of these mechanisms. For example, active and passive vaccination (Bae et al., 2012; Lindström et al., 2014) prevented neurodegeneration and reduced $\alpha$-syn accumulation by promoting clearance via autophagy (Masliah et al., 2005, 2011; Mandler et al., 2014) and microglial cells (Mandler et al., 2015). Using this mouse model, we showed that active immunization against $\alpha$-syn triggered a strong antibody response with antibodies trafficking into the CNS (Masliah et al., 2005; Mandler et al., 2015). Likewise, modulation of T-cell trafficking with a copolymer has been shown to reduce dopaminergic deficits and inflammation (Laurie et al., 2007). Similarly, passive immunization with monoclonal antibodies recognizing the $\mathrm{N}$ terminus (Shahaduzzaman et al., 2015) and C terminus of $\alpha$-syn ameliorated behavioral deficits, reduced neurodegeneration, and $\alpha$-syn accumulation in neurons (Masliah et al., 2011) as well as in glial cells (Bae et al., 2012) by reducing the cell-to-cell transmission of $\alpha$-syn (Bae et al., 2012; Valera and Masliah, 2013; Games et al., 2014) and prion-like propagation (Tran et al., 2014).

Recent preclinical studies have shown that these active, passive, and cellular immunization approaches are safe, and some of them are currently under clinical development. However, it is unknown whether combining humoral and cellular immunization might synergistically reduce inflammation and improve microglial-mediated $\alpha$-syn clearance. Therefore, we investigated whether combining active cellular and humoral immunization was more effective at ameliorating the deficits associated in models of synucleinopathy than either cellular or humoral immunization alone. Rapamycin (RAP) has been used as part of a combination immunotherapy in other diseases, including tuberculosis and influenza (Jagannath and Bakhru, 2012; Keating et al., 2013), and recent clinical trials (Mannick et al., 2014; Xie et al., 2016). It has been recently reported that the codelivery of an antigen + RAP in nanoparticles induced antigen-specific $\mathrm{T}$ regulatory cells (iTregs; Maldonado et al., 2015). We adapted this immunization strategy to $\alpha$-syn using the antigen-presenting cell targeting the glucan particle (GP) vaccine delivery system to test the hypothesis that combining humoral and immunosuppressive cellular immunization would synergize to enhance $\alpha$-syn clearance, reduce inflammation, and neuropathological symptoms. For this purpose, $\alpha$-syn transgenic (tg) mice were immunized with the GP vaccine complex and analyzed by neuropathological and immunological markers. We show that the combined vaccination generating iTregs might enhance the effects of active immunotherapy for the treatment of synucleinopathies.

\section{Materials and Methods}

Preparation of the GP vaccine and in vitro testing in the LC3-GFP cell line. It has been shown that the combined delivery of an antigen + RAP in nanoparticles induced antigen-specific Tregs (Maldonado et al., 2015) We adapted this vaccination approach to $\alpha$-syn using the antigenpresenting cell targeting the GP vaccine delivery system (Fig. 1A). For this purpose, the GP vaccines were prepared as follows: (1) GP-alone (200 $\mu \mathrm{g}$ of GP with $10 \mu \mathrm{g}$ of ovalbumin plus $25 \mu \mathrm{g}$ of mouse serum albumin (MSA; carrier protein); (2) GP- $\alpha$-syn (200 $\mu \mathrm{g}$ of GP with $10 \mu \mathrm{g}$ of human $\alpha$-syn plus $25 \mu \mathrm{g}$ of MSA); (3) GP encapsulated RAP alone (200 $\mu \mathrm{g}$ of GP containing $10 \mu \mathrm{g}$ of RAP plus $10 \mu \mathrm{g}$ of ovalbumin plus 25 $\mu \mathrm{g}$ of MSA); and (4) GP coencapsulated RAP/ $\alpha$-syn (200 $\mu \mathrm{g}$ of GP containing $10 \mu \mathrm{g}$ of RAP plus $10 \mu \mathrm{g}$ of human $\alpha$-syn plus $25 \mu \mathrm{g}$ of MSA) using the antigen-adjuvant coloading methods, as previously described (Huang et al., 2009, 2010, 2013; Hurtgen et al., 2012; Cole et al., 2013; Specht et al., 2015).

An immortalized C57BL/6 macrophage cell line expressing microtubule-associated protein 1A/1B-light chain 3 fused to GFP (LC3-GFP) was used to demonstrate that the RAP encapsulated in the GPs was delivered and induced autophagy (Hartman and Kornfeld, 2011). For this purpose, LC3-GFP macrophage cells were plated on glass coverslips and incubated overnight with the following treatments: (1) saline alone (control 1); (2) free RAP (10 $\mu \mathrm{g} / \mathrm{ml}) ;$ (3) GP-alone at 10 particles/cell (control 2); (4) GP+RAP (10 $\mu \mathrm{g} / \mathrm{ml})$; (5) GP+RAP (1 $\mu \mathrm{g} / \mathrm{ml})$; and (6) $\mathrm{GP}+\mathrm{RAP}(0.1 \mu \mathrm{g} / \mathrm{ml})$ and processed for fluorescent microscopy on the following day to determine the formation of LC3-GFP punctae. Fluorescent puncta (white arrows) indicate autophagy induction. Free rapamycin (10 $\mu \mathrm{g} / \mathrm{ml}$ ) stimulates autophagy over saline and empty GP controls. GP encapsulated rapamycin efficiently stimulates autophagy between 0.1 and $10 \mu \mathrm{g} / \mathrm{ml}$.

Mouse model and immunotherapy. For these experiments, we used 6-month-old (male and female) mice overexpressing human $\alpha$-syn under the PDGF $\beta$ promoter (PDGF $\beta \alpha$-syn, Line D; Masliah et al., 2000) and age-matched (male and female) non-tg mouse littermates. The Line D model was selected because these mice develop behavioral deficits (Amschl et al., 2013), axonal pathology, neurodegeneration, neuroinflammation, and accumulate $\alpha$-syn in the neocortex and limbic system mimicking DLB-like pathology (Lee et al., 2010). Moreover, this model has been previously used for proof-of-concept studies of active and passive vaccination and showed that the antibodies penetrate the CNS, recognize $\alpha$-syn in aggregates in neurons, and reduce the accumulation of $\alpha$-syn in the brain (Masliah et al., 2005, 2011). These studies have provided important preclinical data that have informed the advancement of immunotherapeutics to early-stage clinical trials in patients with PD.

A total of $n=30$ ( $n=6$ non-tg, $n=24 \mathrm{tg}$ ) age-matched and genderbalanced mice were used for this study. For each group $n=6$ non-tg and $n=6$ tg mice were treated with the following vaccines: (1) GP-alone (control 1); (2) GP- $\alpha$-syn (active immunization); (3) GP+RAP (control 2 ); and (4) GP $+\mathrm{RAP} / \alpha$-syn (combined active and Treg vaccine). Mice were 6 months old at the start of the treatment, each mouse was injected intraperitoneally with $0.1 \mathrm{ml}$ every other week for 4 weeks and killed 4 weeks after the last injection (between 7.5 and 8 months of age). This timeline has previously been shown to produce antibody titer levels sufficient to interfere with $\alpha$-syn (Masliah et al., 2005). All experiments described were performed according to National Institutes of Health guidelines for animal use, approved by the animal use and care committee of the University of California, San Diego, randomized, and had power calculations performed.

Tissue processing. Mice were anesthetized with chloral hydrate, and terminal blood sampling was performed. Blood was saved in EDTAtreated tubes and spun for subsequent serological analysis. Then brains were removed and divided sagittally, the left hemibrain was postfixed in phosphate-buffered $4 \%$ paraformaldehyde, $\mathrm{pH} \mathrm{7.4}$, at $4^{\circ} \mathrm{C}$ for $48 \mathrm{~h}$ and sectioned at $40 \mu \mathrm{m}$ with a Vibratome (Leica) for immunocytochemical 


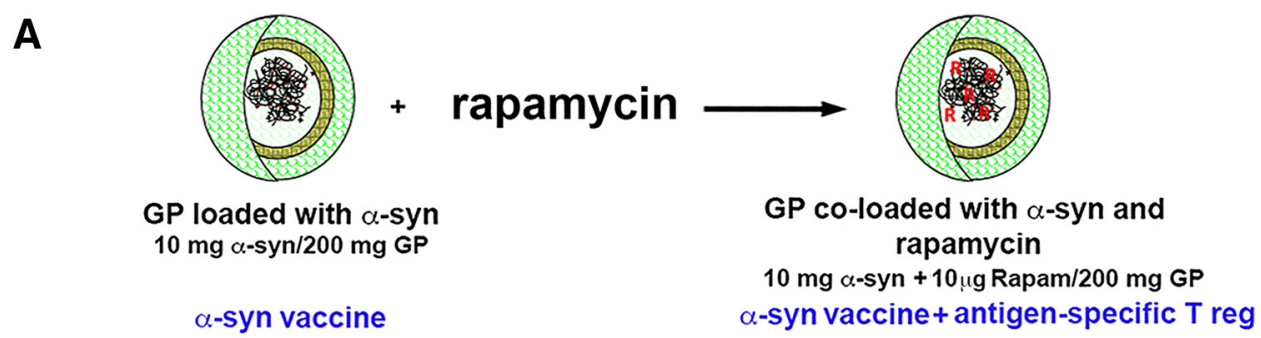

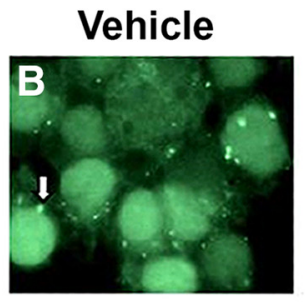
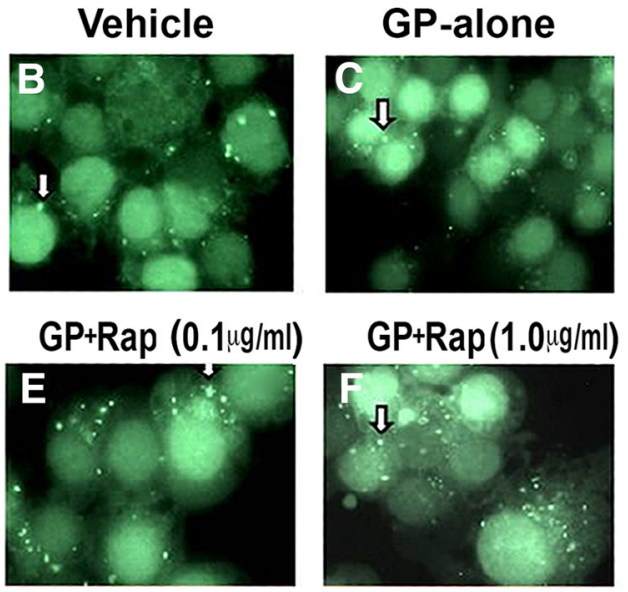
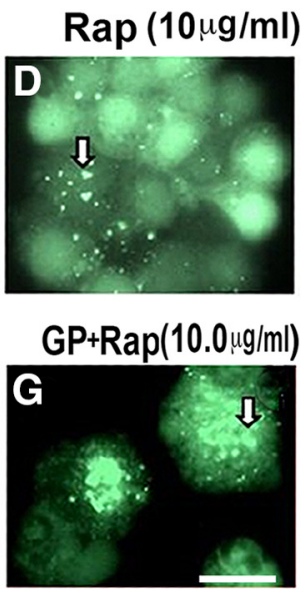

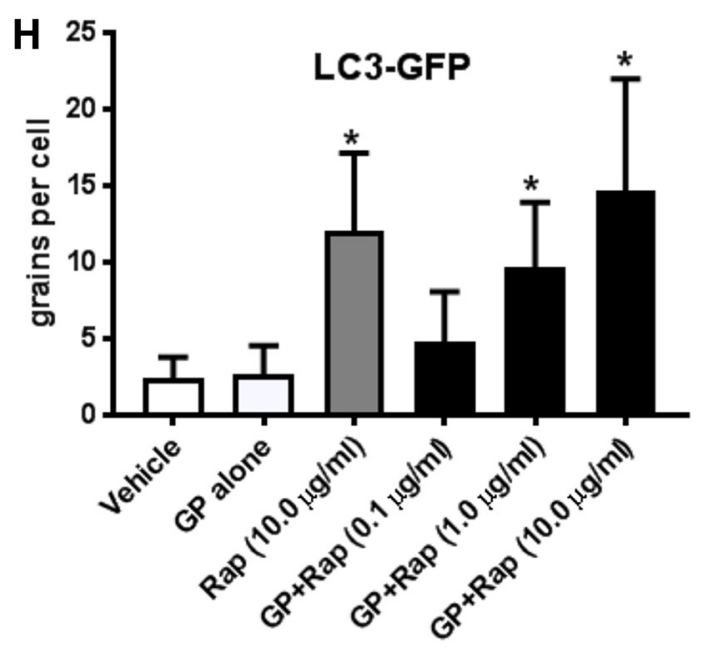

Figure 1. Diagrammatic representation of the preparation of the vaccine and in vitro verification of GP + RAP to induce autophagy in the LC3-GFP macrophage cell line. $A$, Schematic representation of the GP vaccine delivery system loaded with $\alpha$-syn, designated as GP- $\alpha$-syn (left), which could also be coloaded with RAP and designated as GP + RAP/ $\alpha$-syn (right). B, C, Macrophages expressing LC3-GFP that were treated with vehicle (saline) (B) or GP-alone ( $\boldsymbol{C}$ ) displayed few LC3-GFP-positive punctae (arrows). $\boldsymbol{D}-\mathbf{G}$, Macrophages treated with RAP (10 $\mu \mathrm{g} / \mathrm{ml} ; \mathbf{D})$ and increasing concentrations of GP + RAP $[0.1(\boldsymbol{E}), 1.0(\boldsymbol{F})$, and $10 \mu \mathrm{g} / \mathrm{ml}(\boldsymbol{G})]$ showed dose-dependent increases in LC3-GFP-positive grains. $\boldsymbol{H}$, Quantification of the number of LC3-GFP-positive grains per cell. ${ }^{*} p<0.05$ using ANOVA followed by Dunnett's post hoc test compared with control-treated cells. Scale bar, $15 \mu \mathrm{m}$.

analysis, while the right hemibrain was snap frozen and stored at $-70^{\circ} \mathrm{C}$ for subsequent fractionation and immunoblot analysis.

Serological studies. Control and vaccinated mouse sera were diluted as indicated in PBS $+0.05 \%$ Tween 20 (wash buffer) and analyzed by ELISA. Human recombinant $\alpha$-synuclein (10 ng/well) was bound to Costar 3695-96 well microtiter plates in Binding Buffer (eBioscience), washed three times with wash buffer, blocked with Blocking Buffer (eBioscience), and washed three times with wash buffer, and diluted sera were added in triplicate. After $2 \mathrm{~h}$ of incubation at room temperature, wells were washed three times with wash buffer and the following secondary antibodies were added: total IgG (dilution 1:500; goat anti-mouse IgGhorseradish peroxidase (HRP), catalog \#A16072, Life Technologies), IgG1 (dilution 1:5000; goat anti-mouse IgG1-HRP, catalog \#1071-05, SBiotech), and IgG2a (dilution 1:5000; goat anti-mouse IgG2a-HRP, catalog \#1081-05, SBiotech) for $1 \mathrm{~h}$ at room temperature. After washing, the plate was developed with TMB Substrate Solution (catalog \#88-732488 , eBioscience), stopped with $2 \mathrm{~N}$ sulfuric acid, and absorbance was measured at an optical density (OD) of 405 . The standard concentration curves of primary anti- $\alpha$-synuclein antibodies were (1) total IgG and (2) IgG1 (0-500 ng/ml; $\alpha$ Synuclein Monoclonal Antibody Syn 211, Invitrogen), and (3) IgG2a (0-500 ng/ml; $\alpha$ Synuclein Monoclonal Antibody Syn 202, Invitrogen) and were detected with the isotype-specific HRP-conjugated antibodies as described above and used to determine $\alpha$-syn antibody sera concentrations.

Tissue fractionation and Western blot analysis. Briefly, as previously described, the frozen cortex and hippocampus were homogenized and separated by ultracentrifugation into cytosolic and membrane fractions (Tofaris et al., 2003). For immunoblot analysis, $20 \mu \mathrm{g}$ of protein per lane were loaded into $4-12 \%$ Bis-Tris SDS-PAGE gels and blotted onto polyvinylidene fluoride membranes. To determine the effects of vaccination on $\alpha$-syn levels, blotted samples from treated $\alpha$-syn tg mice were probed with an antibody against full-length $\alpha$-syn (1:1000; monoclonal, SYN-1,
BD Biosciences; Masliah et al., 2011) and an antibody against human $\alpha$-syn (1:2000; monoclonal, SYN211, Millipore). To evaluate the effects of the combined vaccine of immunological markers, the blots were probed with antibodies against CD25 (1:1000; monoclonal, MBL); TGF- $\beta 1$ (polyclonal, 1:2500, Abcam); CD68 (1:1000; monoclonal, Abcam), TNF- $\alpha$ (1: 2000; polyclonal, Abcam), and IL-6 (1:1000; polyclonal, Santa Cruz Biotechnology).

Incubation with primary antibodies was followed by species-appropriate incubation with secondary antibodies tagged with horseradish peroxidase (1:5000; Santa Cruz Biotechnology), visualization with enhanced chemiluminescence, and analysis with a Versadoc XL imaging apparatus (Bio-Rad). Analysis of $\beta$-actin (Sigma-Aldrich) levels was used as a loading control.

Immunocytochemical studies of $\alpha$-syn, markers of neurodegeneration, inflammation, and immune response. Analysis of $\alpha$-syn accumulation was performed using vibratome-cut free-floating coronal brain sections $(40 \mu \mathrm{m})$. Brain sections were incubated overnight at $4^{\circ} \mathrm{C}$ with a monoclonal antibody against total $\alpha$-syn (1:500; SYN-1, BD Systems; Masliah et al., 2000; Games et al., 2013) in the presence or absence of proteinase K ( $10 \mu \mathrm{g} / \mathrm{ml}$ for $15 \mathrm{~min}$ ) or nonimmune IgG controls (background levels), phosphor Ser129 $\alpha$-syn (1:250; rabbit monoclonal, Abcam,), a neuronal marker (1:2500; NeuN, mouse monoclonal, Millipore), an astroglial cell marker [1:2500; glial fibrillary acidic protein (GFAP), mouse monoclonal, Millipore], a dopaminergic neuron marker (1:1000; TH, mouse monoclonal, Millipore), a microglial cell marker (1:5000; Iba1, goat polyclonal, Abcam), a Treg marker (1:250; CD25, monoclonal, MBL), a B-cell marker (1:100; CD20, mouse monoclonal, Millipore), a marker of learning and memory (1:500; Arc, rabbit polyclonal, Santa Cruz Biotechnology), an anti-CD68 (1:100; monoclonal, Abcam), an anti-FOXP3 (1:250; monoclonal, Abcam), a T-cell marker (1:250; CD4, monoclonal, Abcam), or anti-TGF- $\beta 1$ (1:500; polyclonal, Abcam) followed by incubations with secondary antibodies biotinylated (1:100, Vector Laboratories), Avidin D-HRP (1:200; ABC Elite, Vector Labo- 
ratories), and detection with 3,3'-diaminobenzidine (Masliah et al., 2011). All sections were processed simultaneously under the same conditions, and experiments were performed in triplicate to assess the reproducibility of results.

Sections were analyzed with an Olympus BX41 Digital Video Microscope equipped with an Optronics Magna Fire SP Camera, LucisTM DHP unique contrast enhancement software, and Image Pro Express (Media Cybernetics) for live image acquisition and processing at $630 \times$ magnification. For each section, four areas of interest $(1024 \times 1024$ pixels) within the neocortex and hippocampus, were analyzed in real time using the Image-Pro Plus program. $\alpha$-Syn and GFAP levels of immunoreactivity were expressed as corrected OD (arbitrary units). Sections labeled with Iba- 1 were analyzed using the Image-Pro Plus program (Media Cybernetics; 10 digital images/section at $400 \times$ magnification) and analyzed to estimate the average number of immunolabeled cells per unit area $\left(100 \mu \mathrm{m}^{2}\right)$. Sections with LC3-GFP-positive punctae were counted semiautomatically with a macro available in ImageJ, as previously described (Suberbielle et al., 2015). Sections were scanned with a digital Olympus bright-field digital microscope (model BX41). Briefly, as previously described (Overk et al., 2014), the numbers of NeuNimmunoreactive neurons in the hippocampus were estimated using unbiased stereological methods. The CA3 region of the hippocampus was outlined using an Olympus BX51 Microscope running StereoInvestigator version 8.21.1 software (MBF Bioscience; grid sizes, $150 \times 150 \mu \mathrm{m}$; counting frames, $30 \times 30 \mu \mathrm{m})$. The average coefficient of error for each region was $<0.1$. Sections were analyzed using a $100 \times 1.4$ PlanApo oil-immersion objective. The average mounted tissue thickness allowed for $2 \mu \mathrm{m}$ guard-zones at top and bottom and a 5- $\mu \mathrm{m}$-high dissector.

Double immunolabeling and confocal microscopy. Briefly, to evaluate the effects of immunization on $\alpha$-syn clearance via immune cells, as previously described (Bae et al., 2012), sections were double labeled with antibodies against $\alpha$-syn (1:500; Millipore) detected with Tyramide Signal Amplification-Direct (Red) system and microglial markers (1:2500; Wako) detected with FITC. All sections were processed simultaneously under the same conditions, and experiments were performed in triplicate to assess the reproducibility of results. Sections were imaged with a Zeiss $63 \times$ (numerical aperture, 1.4) objective on an Axiovert 35 Microscope (Zeiss) with an attached MRC1024 LSCM (laser-scanning confocal microscope) System (Bio-Rad; Masliah et al., 2000). Image analysis was performed using ImageJ, as previously described (Marxreiter et al., 2013), to determine the percentage of immune cells displaying $\alpha$-syn immunoreactivity.

Experimental design and statistical analysis. All experiments were performed blind coded and in triplicate. Values in the figures are expressed as the mean \pm SEM. To determine the statistical significance, values were compared using one-way ANOVA with Dunnett's post hoc test, as indicated in each figure legend. Adjusted $p$ values are reported for specific comparisons in the Results section. Each analysis had $25 \mathrm{df}$ with the exception of the proteinase K (PK) PK- $\alpha$-syn and pSer- $\alpha$-syn experiments (see Fig. 6), which had 20 df. The differences were considered to be significant if the $p$ value was $<0.05$.

\section{Results}

\section{The GP vaccine is active in vitro and elicits serological and Treg responses in vivo}

To verify the activity of the GP vaccine in vitro, macrophages expressing LC3-GFP were treated with GP-alone or GP+RAP $(0.1-10 \mu \mathrm{g} / \mathrm{ml})$. Under baseline conditions, macrophages treated with saline (Fig. $1 B$ ) or GP-alone (Fig. $1 C$ ) displayed only a few LC3-GFP-positive punctae. In contrast, treatment with RAP (10 $\mu \mathrm{g} / \mathrm{ml}$ ) alone resulted in a considerable increase in punctae per cell compared with GP-alone (Fig. $1 D, p=0.0005$ ); likewise, treatment with the GP+RAP resulted in dose-dependent increases in LC3-GFP-positive grains (Fig. $1 E-H$ ) with both 1 $\mu \mathrm{g} / \mathrm{ml}(p=0.0116)$ and $10 \mu \mathrm{g} / \mathrm{ml}(p=0.0001)$ doses having significant increases compared with GP-alone. Next, we analyzed the titers of total IgG, IgG1, and IgG2a anti- $\alpha$-syn antibody gen- eration in the sera by ELISA. For the present study, analysis by ELISA showed that vaccination with GP- $\alpha$-syn or GP $+\mathrm{RAP} / \alpha$ syn resulted in high-level titers of total IgG, IgG1, and IgG2a compared with GP-alone negative control (Fig. 2, Table 1). These studies support the notion that the GP vaccine is active and promotes the generation of high levels of anti- $\alpha$-syn antibodies.

For all experiments, Line D mice were used (PDGF $\beta$ - $\alpha$-syn tg; Masliah et al., 2000; Amschl et al., 2013) because these animals mimic pathological and functional aspects of DLB, including accumulation of $\alpha$-syn in the neocortex and hippocampus and degeneration in layers 5-6 of the neocortex and CA3 of the hippocampus (Amschl et al., 2013).

Next, we evaluated the effects of the GP vaccine on T and B cells in the CNS by immunostaining sections from the mice with antibodies against CD4 (T cells), CD25 (Treg), FOXP3 (Treg), and 20CD20 (B cells). In non-tg and $\alpha$-syn tg mice treated with $\mathrm{GP}$, only rare CD4-positive cells were detected (Fig. $3 A, B$ ). In mice treated with GP- $\alpha$-syn, some scattered CD4-positive cells were found (Fig. $3 A, B$ ). In contrast, mice treated with GP+RAP $(p=0.0001)$ or $\mathrm{GP}+\mathrm{RAP} / \alpha$-syn $(p=0.0001)$ displayed abundant CD4-positive cells scattered in the neuropil or in proximity with blood vessels compared with non-tg mice treated with GPalone (Fig. $3 A, B$ ). Similarly, mice treated with GP-alone or GP$\alpha$-syn showed some scattered CD25 (Fig. 3C,D) and FOXP3 ${ }^{+}$ cells (Fig. $3 E, F)$, while mice immunized with GP+RAP $(p=$ $0.0001)$ or $\mathrm{GP}+\mathrm{RAP} / \alpha$-syn $(p=0.0001)$ displayed abundant CD25 (Fig. $3 C, D ; p=0.0001$ for both comparisons) and FOXP ${ }^{+}$Treg cells (Fig. $3 E, F ; p=0.0001$ for both comparisons). With CD20, only a few positive cells were observed, with no differences between non-tg and tg mice or among groups (Fig. $3 G, H$ ). Consistent with the immunocytochemical analysis, our Western blot data demonstrates that levels of CD25 and FOXP3 were increased in the brains of mice vaccinated with GP+RAP ( $p=0.0002$ and 0.0001 , respectively) and GP $+\mathrm{RAP} / \alpha$-syn ( $p=0.0001$ and 0.0001 , respectively) compared with $\alpha$-syn tg animals treated to GP-alone (Fig. $4 A-C$ ). In summary, these data show that the GP $+\mathrm{RAP} / \alpha$-syn vaccine elicited a potent antibody response and elicited Tregs (CD25 and FOXP3) in the CNS of tg mice.

\section{The GP vaccine reduces the accumulation of $\alpha$-syn in the brains of $\mathrm{tg}$ mice and ameliorates neurodegeneration}

As expected, in non-tg mice stained with an antibody against total $\alpha$-syn, which also recognizes endogenous murine $\alpha$-syn, immunoreactivity was detected only in the neuropil, but no staining was seen in the neuronal cell bodies (Fig. $5 A$ ). In contrast, in tg mice there was increased $\alpha$-syn accumulation in the neuropil and cell bodies in the neocortex and hippocampus (Fig. 5A). Compared with GPalone or GP+RAP, tg mice vaccinated with GP- $\alpha$-syn $(~ p=0.0001$; $p=0.0004$, respectively) or $\mathrm{GP}+\mathrm{RAP} / \alpha$-syn $(p<0.0001 ; p<$ 0.0001 , respectively) displayed a significant reduction in $\alpha$-syn accumulation in the neuropil and neuronal cell bodies in the neocortex (Fig. 5A,B). Moreover, GP+RAP/ $\alpha$-syn significantly decreased $\alpha$-syn accumulation compared with GP- $\alpha$-syn treatment (Fig. $5 A, B ; p=0.0352$ ). Likewise, the hippocampus displayed a significant reduction in $\alpha$-syn accumulation in the neuropil and neuronal cell bodies (Fig. $5 A, C$ ) when comparing tg mice vaccinated with $\mathrm{GP}$-alone or GP+RAP to tg mice vaccinated with GP- $\alpha$-syn ( $p=$ 0.0003 and 0.0009 , respectively) or $\mathrm{GP}+\mathrm{RAP} / \alpha$-syn $(p=0.0001$ and 0.0001 , respectively).

To evaluate the effects of the GP vaccine on aggregated $\alpha$-syn species, immunocytochemical analysis was performed in sections pretreated with PK or with an antibody against pSer 129- $\alpha$-syn. In non-tg mice, no $\alpha$-syn immunostaining was detected in the neo- 
A GP- $\alpha-$ syn
total lgG

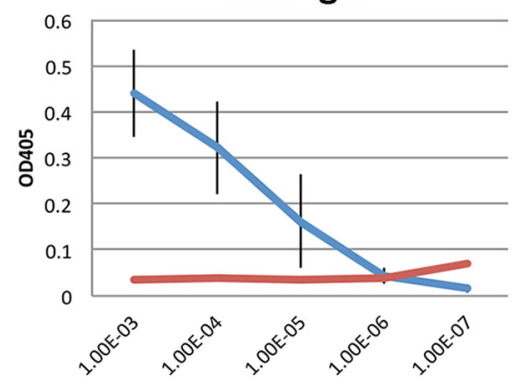

C

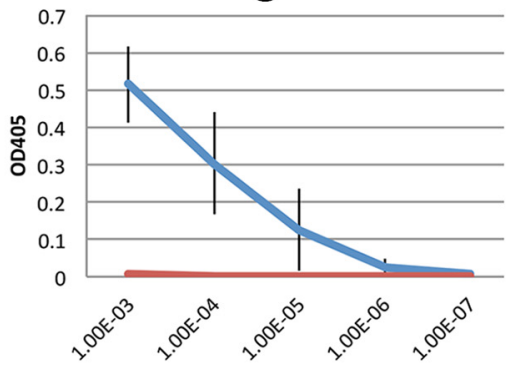

E

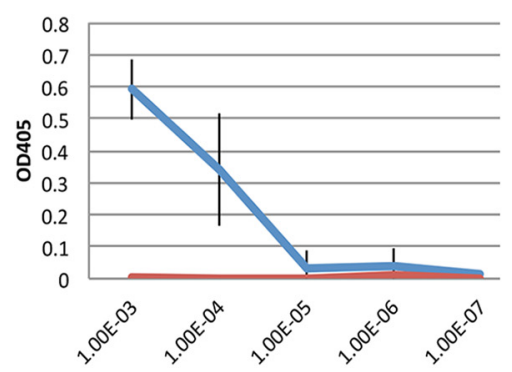

B

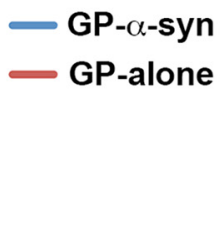

\section{- GP- $\alpha$-syn \\ GP-alone}

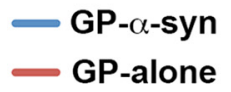

$\mathbf{F}$
GP+RAP/ $\alpha$-syn total IgG

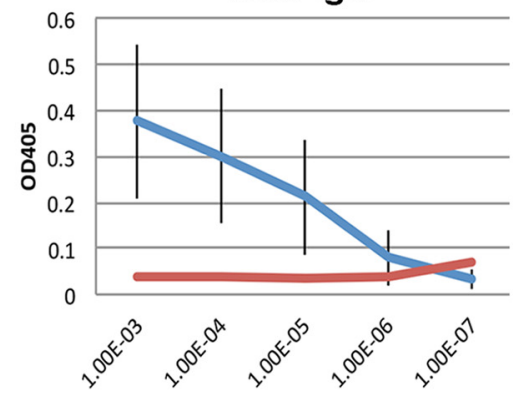

- GP+RAP/ $\alpha$-syn GP-alone

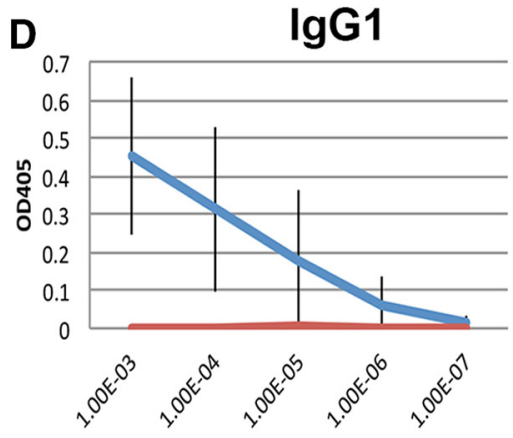

- GP+RAP/ $\alpha$-syn

$\lg \mathrm{G} 2 \mathrm{a}$

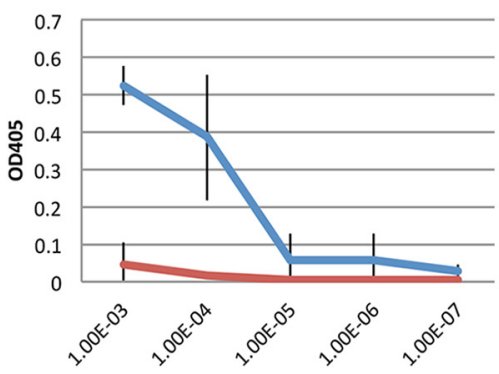

GP+RAP/ $\alpha$-syn GP-alone

Figure 2. Antibody titers in response to GP- $\alpha$-syn ${ }^{+/-}$RAP vaccination in tg mice. $\alpha$-Syn $\operatorname{tg}($ Line D) mice and non-tg littermates were injected biweekly intraperitoneally for 4 weeks and killed 4 weeks after the last injection (7.5-8 months of age). $\boldsymbol{A}, \boldsymbol{B}$, Total lgG was increased in GP- $\alpha$-syn-immunized $(\boldsymbol{A})$ and GP + RAP/ $\alpha$-syn-immunized ( $\boldsymbol{B})$ mice (blue lines, respectively) compared with their negative controls (red lines, respectively). $\boldsymbol{C}-\boldsymbol{F}$, Similarly, $\lg G 1(\boldsymbol{C}, \boldsymbol{D})$ and $\lg G 2 \mathrm{a}(\boldsymbol{E}, \boldsymbol{F})$ serum levels were increased for mice vaccinated with $\mathbf{G P}$ - $\alpha$-syn $(\boldsymbol{C}$ and $\boldsymbol{E}$, blue lines, respectively) and $\mathrm{GP}+\mathrm{RAP} / \alpha$-syn ( $\boldsymbol{D}$ and $\boldsymbol{F}$, blue lines, respectively) compared with their negative controls (red lines). $N=6$ per treatment group. Blue lines represent vaccination with GP $+\mathrm{RAP} / \alpha$-syn or GP- $\alpha$-syn, while the red lines represent the respective controls with GP-alone.

Table 1. Antibody titers in response to combined syn vaccination in tg mice

\begin{tabular}{llll}
\hline Mouse serum $^{a}$ & Total lgG $(\mathrm{ng} / \mathrm{ml})$ & $\operatorname{lgG1}(\mathrm{ng} / \mathrm{ml})$ & $\operatorname{lgG2a}(\mathrm{ng} / \mathrm{ml})$ \\
\hline Negative control & 0 & 0 & 0 \\
GP $\alpha$-syn vaccine & $2530.4 \pm 881.5$ & $5524 \pm 1707.4$ & $3750 \pm 1896.1$ \\
GP $\alpha$-syn + RAP vaccine & $3965.1 \pm 461.5$ & $4479 \pm 342$ & $3926 \pm 1531.6$
\end{tabular}

Data are presented as the average \pm SD.

${ }^{a}$ Mouse serum was diluted 1:10,000 for the total $\lg G$ and $\lg G 1$ analysis and 1:1,000 for $\lg G 2$ a.

cortex and hippocampus with PK treatment (Fig. 6A-C) or with anti-pSer129 (Fig. 6D-F). The tg mice treated with GP-alone or $\mathrm{GP}+\mathrm{RAP}$ displayed high levels of PK-resistant $\alpha$-syn (Fig. 6A, $B$ ) in the neocortex. In contrast, tg mice vaccinated with GP+RAP/ $\alpha$-syn showed a significant reduction in PK-resistant $\alpha$-syn accumulation (Fig. $6 A, B)$ compared with GP-alone $(p=0.0001)$ and $\mathrm{GP}+\mathrm{RAP}(p=0.0001)$, and a trend toward reduction compared with GP- $\alpha$-syn $(p=0.0683)$. A similar reduction in PK-resistant $\alpha$-syn accumulation was seen in the hippocampus (Fig. $6 A, C$ ) with $\mathrm{GP}+\mathrm{RAP} / \alpha$-syn treatment compared with GP-alone $(p=$ $0.0003)$, GP- $\alpha$-syn $(p=0.0369)$, and GP+RAP $(p=0.0369)$.
pSer129- $\alpha$-syn immunoreactivity (Fig. 6) was also increased in neurons in the deep layers of the neocortex (Fig. 6A) and CA3 of the hippocampus (Fig. 6D). Additionally, pSer129 $\alpha$-syn (Fig. 6D) accumulation in the neocortex (Fig. $6 E$ ) was significantly reduced with $\mathrm{GP}+\mathrm{RAP} / \alpha$-syn treatment compared to GP-alone ( $p=$ $0.0051)$ or GP+RAP ( $p=0.0001)$. GP- $\alpha$-syn also significantly reduced pSer $\alpha$-syn accumulation compared to GP+RAP ( $p=$ 0.0013). In the hippocampus (Fig. $6 F$ ), GP- $\alpha$-syn and GP $+\mathrm{RAP} / \alpha$ syn treatments significantly reduced $\mathrm{pSer}-\alpha$-syn compared with treatment with GP-alone ( $p=0.0001$ and 0.0001 , respectively) and GP+RAP (0.0002 and 0.0001, respectively). Consistent with these results, Western blot analysis showed that levels of insoluble $\alpha$-syn were reduced in the brains of tg mice vaccinated with GP- $\alpha$-syn or $\mathrm{GP}+\mathrm{RAP} / \alpha$-syn compared to animals treated with GP-alone ( $p=$ 0.0394 and 0.0001 , respectively) or GP+RAP (Fig. $4 A, D ; p=0.0001$ and 0.0001 , respectively).

Next, we investigated the effects of the GP vaccine on ameliorating the neurodegenerative phenotype in tg mice. We have previously shown that in aged $\alpha$-syn tg mice there is a loss of neurons 
A

A Non-tg

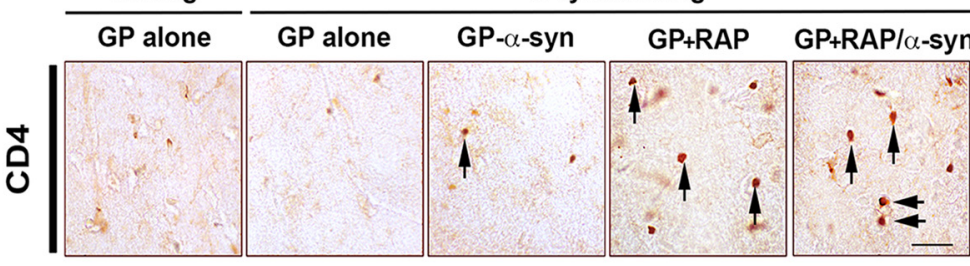

C

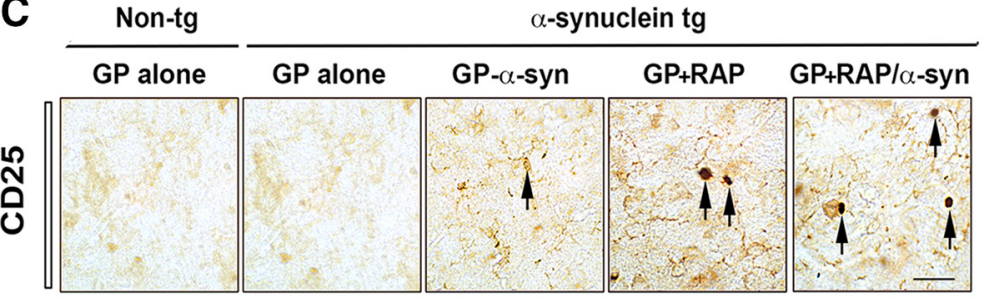

E

Non-tg
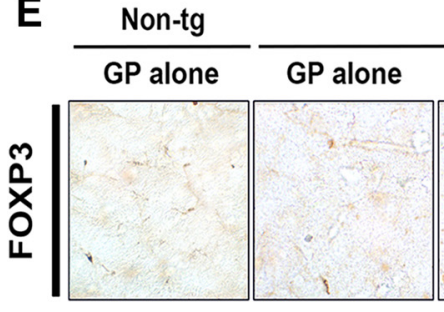

$\alpha$-synuclein $\mathrm{tg}$

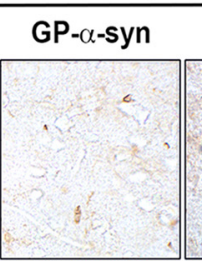

GP+RAP

GP+RAP/ $\alpha-$ syrn

G

G Non-tg

GP alone

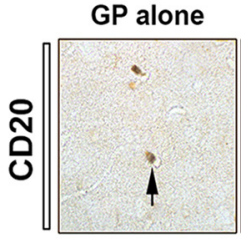

$\alpha$-synuclein tg

\begin{tabular}{|c|c|c|c|}
\hline GP alone & GP- $\alpha$-syn & GP+RAP & GP+RAP/ $\alpha-s y n$ \\
\hline$i^{*}$ & , & r: & $i$ \\
\hline
\end{tabular}

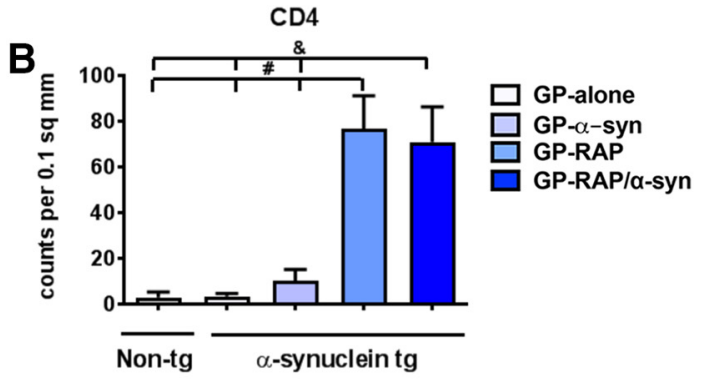

D

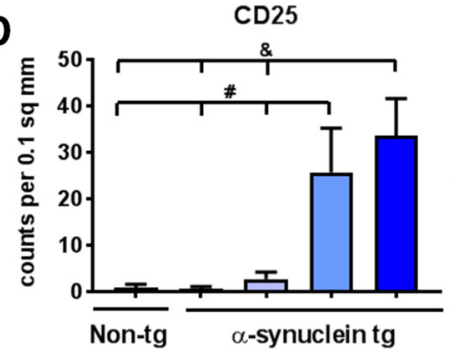

$\square$ GP-alone

GP- $\alpha-s y n$ GP-RAP GP-RAP/a-syn

E

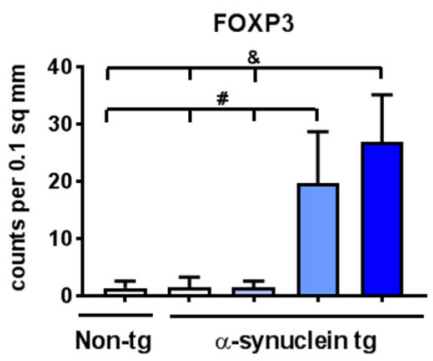

$\square$ GP-alone

$\square$ GP- $\alpha-s y n$ $\square$ GP-RAP GP-RAP/ $\alpha-s y n$

H

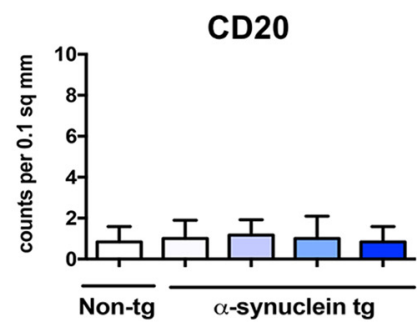

Figure 3. Effects of combined GP+RAP/ $\alpha$-syn vaccination on the trafficking of T and B cells in the brains of $\alpha$-syn tg mice. Brain sections from $\alpha$-syn tg mice immunized with GP, GP- $\alpha$-syn, $G P+R A P$, or GP + RAP/ $\alpha$-syn and non-tg control mice immunized with GP were analyzed immunohistochemically for markers of T cells (CD4), Tregs (CD25, FOXP3), and B cells (CD20). $A-F$, There was a significant increase in the numbers of the CD4-immunoreactive T cells $(\boldsymbol{A}, \boldsymbol{B})$, the CD25 cells $(\boldsymbol{C}, \boldsymbol{D})$, and the F0XP3 markers of Tregs $(\boldsymbol{E}, \boldsymbol{F})$ in $\alpha$-syn tg mice treated with either GP + RAP or $\mathrm{GP}+\mathrm{RAP} / \alpha$-syn compared with non-tg mice treated with GP-alone. $G, \boldsymbol{H}$, There was no change in the CD20 marker for $B$ cells across any of the treatment groups. $p<0.05$ using ANOVA followed by Dunnett's post hoc test comparing GP + RAP/ $\alpha$-syn (\&) or GP + RAP (\#) treatment with all other groups. $N=6$ mice/group. Scale bar, $25 \mu \mathrm{m}$.

in deeper layers of the neocortex and CA3 of the hippocampus (Overk et al., 2014). Consistent with these reports, compared with vehicle-treated non-tg mice, $\alpha$-syn tg mice treated with GPalone $(p=0.0001), \mathrm{GP}-\alpha$-syn $(p=0.0024)$, and GP+RAP $(p=$ 0.0001 ) showed a $25-30 \%$ reduction in the estimated number of NeuN-positive neurons in layers 5-6 of the neocortex (Fig. $7 A, B$ ). In CA3 pyramidal neurons in the hippocampus (Fig. $7 A, C)$, there was a $45-50 \%$ decrease in the estimated number of NeuN-positive neurons with GP-alone ( $p=0.0001), \mathrm{GP}-\alpha$-syn $(p=0.0091)$, or GP $+\operatorname{RAP}(p=0.0001)$ treatment compared to non-tg mice. In contrast, treatment with $\mathrm{GP}+\mathrm{RAP} / \alpha$-syn ameliorated the loss of neurons in the neocortex (Fig. $7 A, B$; $p=0.0001$ ) and hippocampus (Fig. $7 A, C ; p=0.0001$ ) compared to vehicle-treated $\alpha$-syn tg mice. In summary, these studies demonstrate that the GP $+\mathrm{RAP} / \alpha$-syn vaccine reduced the accumulation of $\alpha$-syn and neurodegeneration in the $\alpha$-syn tg mice to a similar if not greater extent than GP- $\alpha$-syn.
Effects of the GP vaccine on markers of functional recovery from neurodegeneration in the brains of $\mathrm{tg}$ mice

We used neuronal activation (Arc) and the dopaminergic system (TH) as biomarkers, which are impacted in this mouse model of $\alpha$-synucleinopathies to assess functional recovery in the $\alpha$-syn tg mice. Compared with non-tg mice, $\alpha$-syn tg mice treated with GP-alone showed decreased neuronal activation in the neocortex (Fig. $8 A, B$; $p$ values $=0.0001$ ). Treatment with $\mathrm{GP}+\alpha$-syn or $\mathrm{GP}+\mathrm{RAP} / \alpha$-syn significantly improved the neuronal activation in $\alpha$-syn tg mice compared to GP-alone treatment in the neocortex (Fig. $8 A, B ; p=0.0386$ and 0.0001 , respectively), with $\mathrm{GP}+\mathrm{RAP} / \alpha$-syn treatment improving neuronal activation to a greater extent than GP $+\alpha$-syn treatment (Fig. $8 A, B ; p=0.0002$ ). Similarly, in the hippocampus, $\alpha$-syn tg mice treated with GPalone had a significant decrease in the Arc biomarker of neuronal activation in $\alpha$-syn tg mice compared to non-tg mice (Fig. $8 C, D$; $p=0.0006)$. Although treatment with $\mathrm{GP}+\alpha$-syn had no signif- 

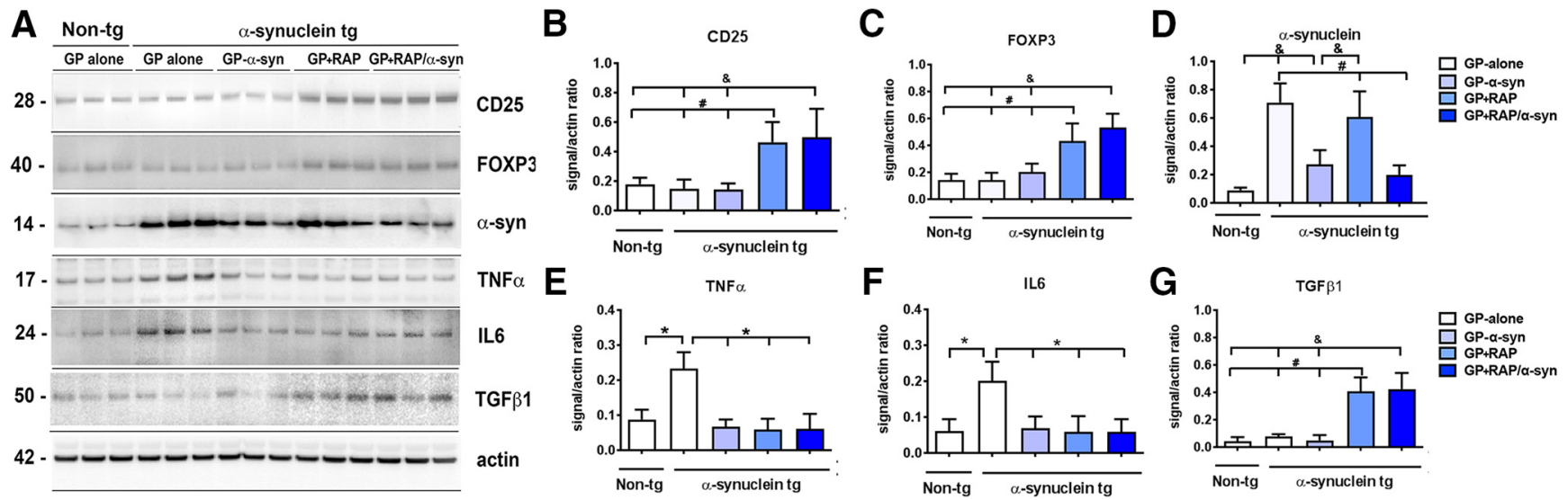

Figure 4. Verification of the effects of combined GP + RAP $/ \alpha$-syn vaccination on $\alpha$-synuclein and immune activation markers by immunoblot. Brain homogenates from $\alpha$-syn tg mice immunized with GP, GP- $\alpha$-syn, GP + RAP, or GP + RAP/ $\alpha$-syn and non-tg control mice immunized with GP were fractioned and analyzed by Western blot. $A-G$, Representative Western blot images $(\boldsymbol{A})$ and quantitative analysis for CD25 (B), FOXP3 (C), $\alpha$-syn (D), TNF- $\alpha(\boldsymbol{E})$, IL-6 $(\boldsymbol{F})$, and TGF- $\beta 1(\boldsymbol{G})$ normalized to actin. $N=6$ mice/group. $p<0.05$ using ANOVA followed by Dunnett's post hoc test comparing each of the other groups with GP-alone treated tg mice $(*), \mathrm{GP}+\mathrm{RAP} / \alpha$-syn $(\&)$, or GP+RAP (\#) treatment.

A

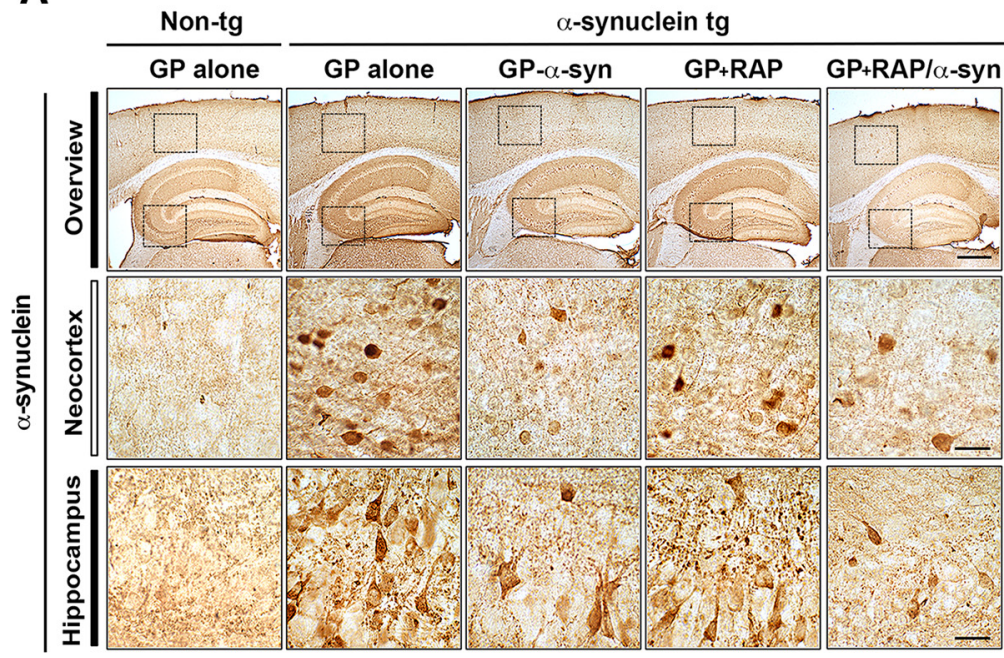

B

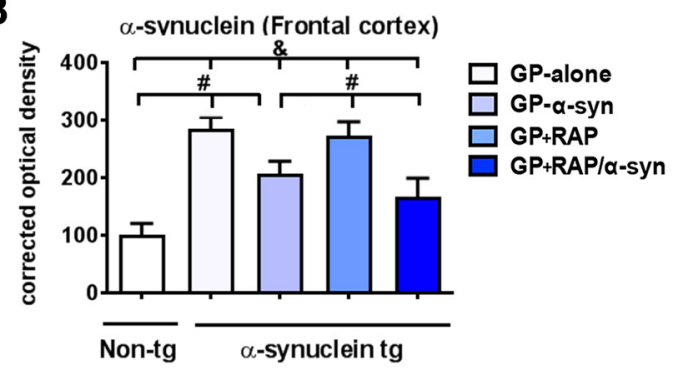

C

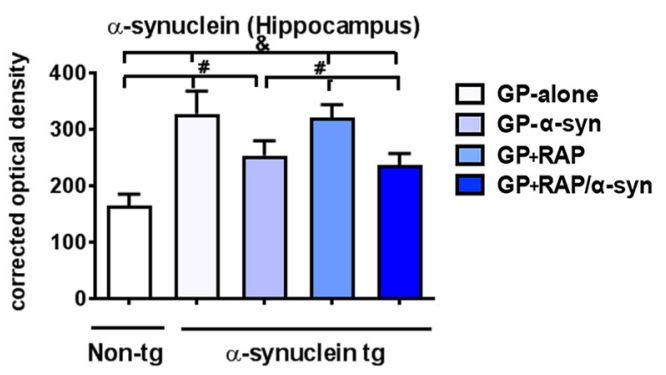

Figure 5. Effects of combined vaccination with GP + RAP/ $\alpha$-syn on levels of total $\alpha$-synuclein in the brains of $\alpha$-syn tg mice. Immunohistochemical analysis of brain sections from $\alpha$-syn tg mice immunized with GP, GP- $\alpha$-syn, GP + RAP, or GP + RAP/ $\alpha$-syn and non-tg control mice immunized with GP was performed using an antibody against total $\alpha$-syn. $\boldsymbol{A}$ - $\boldsymbol{C}$, Representative photomicrographs $(\boldsymbol{A})$ and quantitative analysis of $\alpha$-syn immunoreactivity in the neocortex $(\boldsymbol{B})$ and hippocampus ( $(\boldsymbol{C}$. Compared with non-tg mice immunized with GP-alone, in the $\alpha$-syn tg mice treated with GP-alone there is an extensive accumulation of $\alpha$-syn in the neocortex and hippocampus. Vaccination with GP- $\alpha$-syn and GP $+\mathrm{RAP} / \alpha$-syn significantly reduced the accumulation of $\alpha$-syn. $p<0.05$ using ANOVA followed by Dunnett's post hoc test comparing each of the other groups with GP + RAP/ $\alpha$-syn (\&) or GP- $\alpha$-syn (\#) treatment. $N=6 /$ group. Scale bars: overview, $250 \mu$ m; higher-magnification, $25 \mu \mathrm{m}$.

icant effect (Fig. $8 C, D ; p=0.1351$ ), treatment with $\mathrm{GP}+\mathrm{RAP} / \alpha$ syn significantly improved neuronal activation in $\alpha$-syn tg mice compared with GP-alone (Fig. $8 C, D ; p=0.0003$ ). We also evaluated the functional consequences of these treatments on the dopaminergic system in $\alpha$-syn tg mice. In the striatum, $\alpha$-syn tg mice treated with GP-alone showed a significant decrease in THimmunoreactivity compared with non-tg mice (Fig. $9 A, B ; p=$ $0.0003)$. Treatment with GP- $\alpha$-syn or GP $+\mathrm{RAP} / \alpha$-syn significantly increased TH immunoreactivity in the striatum of $\alpha$-syn tg mice compared to GP-alone treatment (Fig. $9 A, B ; p=0.0013$ and 0.0001 , respectively). However, there were no significant differences in TH immunoreactivity among any of the groups in the substantia nigra (Fig. 9C,D).
Effects of the GP vaccine on immunomodulatory cytokines in the brains of $\operatorname{tg}$ mice

Previous studies have shown that in aged $\alpha$-syn tg mice there are neuroinflammatory changes associated with microgliosis (Iba1), astrogliosis (GFAP), and increased IL- 6 and TNF- $\alpha$ expression (Bae et al., 2012). Given that we have shown that the GP+RAP/ $\alpha$-syn vaccine, in addition to eliciting an anti- $\alpha$-syn antibody response, also induces CD25/FOXP3 cells in the CNS, we hypothesized that Treg signaling with glial cells might further modulate neuroinflammation.

Compared with non-tg mice, $\alpha$-syn tg mice treated with GPalone, GP- $\alpha$-syn, or GP+RAP showed increased numbers of microglial cells in the neocortex (Fig. 10A, $B ; p=0.0001,0.0001$, 
A

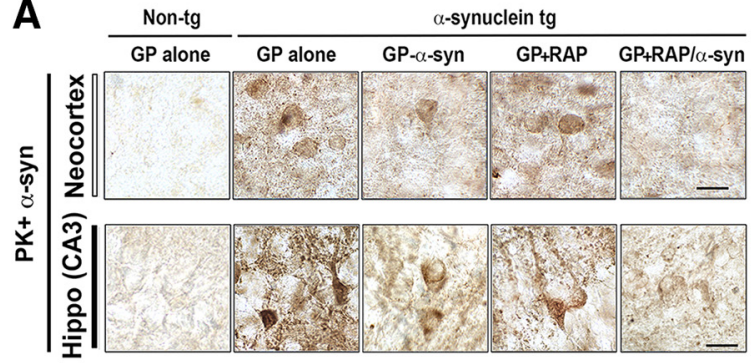

D
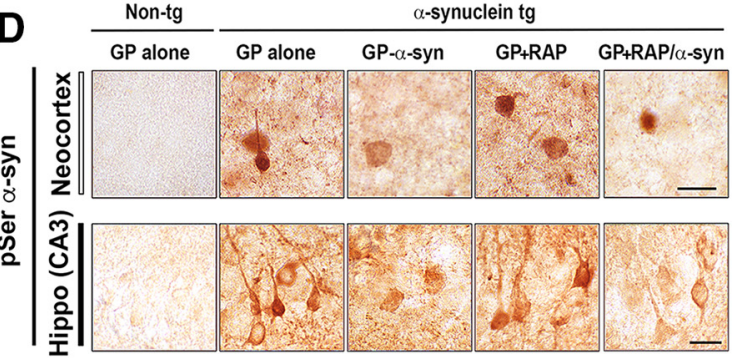

B

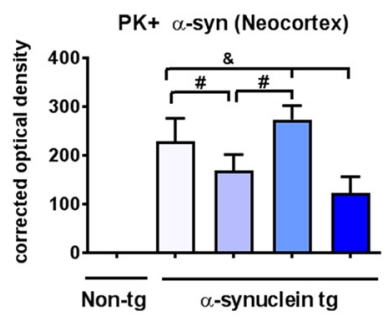

E

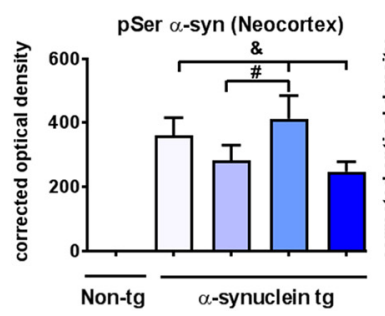

C

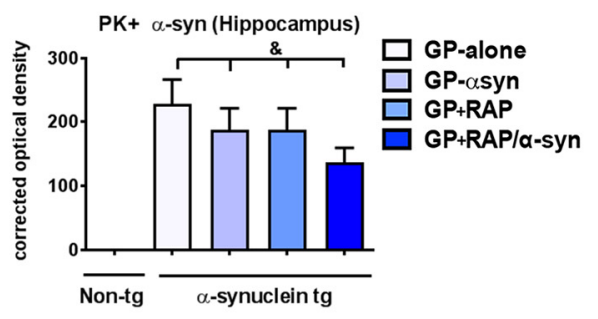

$\mathbf{F}$

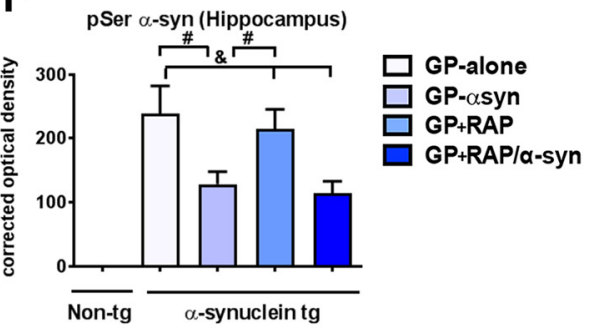

Figure 6. Effects of combined vaccination with GP + RAP/ $\alpha$-syn on levels of PK-resistant and phosphorylated $\alpha$-syn in the brains of $\alpha$-syn tg mice. Immunocytochemical analysis of brain sections pretreated with PK (followed by immunostaining with an antibody against total $\alpha$-syn) or with an antibody against pSer129- $\alpha$-syn in $\alpha$-syn tg mice immunized with GP, GP- $\alpha$-syn, GP + RAP, or $\mathrm{GP}+\mathrm{RAP} / \alpha$-syn and non-tg control mice immunized with GP. $A$, Representative photomicrographs of PK-resistant $\alpha$-syn immunoreactivity in the frontal cortex and hippocampus of immunized $\alpha$-syn tg mice. No immunoreactivity was detected in non-tg mice, while in GP-alone-treated mice there was an accumulation of PK-resistant $\alpha$-syn; treatment with GP- $\alpha$-syn or GP + RAP/ $\alpha$-syn reduced the levels of PK-resistant $\alpha$-syn immunostaining. $\boldsymbol{B}, \mathbf{C}$, Computer-aided quantitation of the OD of PK-resistant $\alpha$-syn immunoreactivity in the frontal cortex (B) and hippocampus (C). $D$, Representative photomicrographs of frontal cortex and CA3 hippocampal sections pretreated with anti-pSer129- $\alpha$-syn from immunized $\alpha$-syn tg mice and non-tg control mice. No immunoreactivity was detected in non-tg mice, while in tg mice treated with GP-alone there was an accumulation of pSer129- $\alpha$-syn; treatment with GP- $\alpha$-syn or GP + RAP/ $\alpha$-syn reduced the levels of pSer129- $\alpha$-syn immunostaining. $\boldsymbol{E}, \boldsymbol{F}$, Computer-aided quantitation of $\alpha$-syn immunoreactivity using 0D from sections pretreated with anti-pSer129 $\alpha$-syn in the frontal cortex $(\boldsymbol{E})$ and hippocampus $(\boldsymbol{F})$. Scale bar, $10 \mu \mathrm{m} . p<0.05$ using ANOVA followed by Dunnett's post hoc test comparing each of the three $\alpha$-syn tg groups with GP + RAP $/ \alpha$-syn (\&) or GP- $\alpha$-syn (\#) treatment. $N=6 /$ group.

A

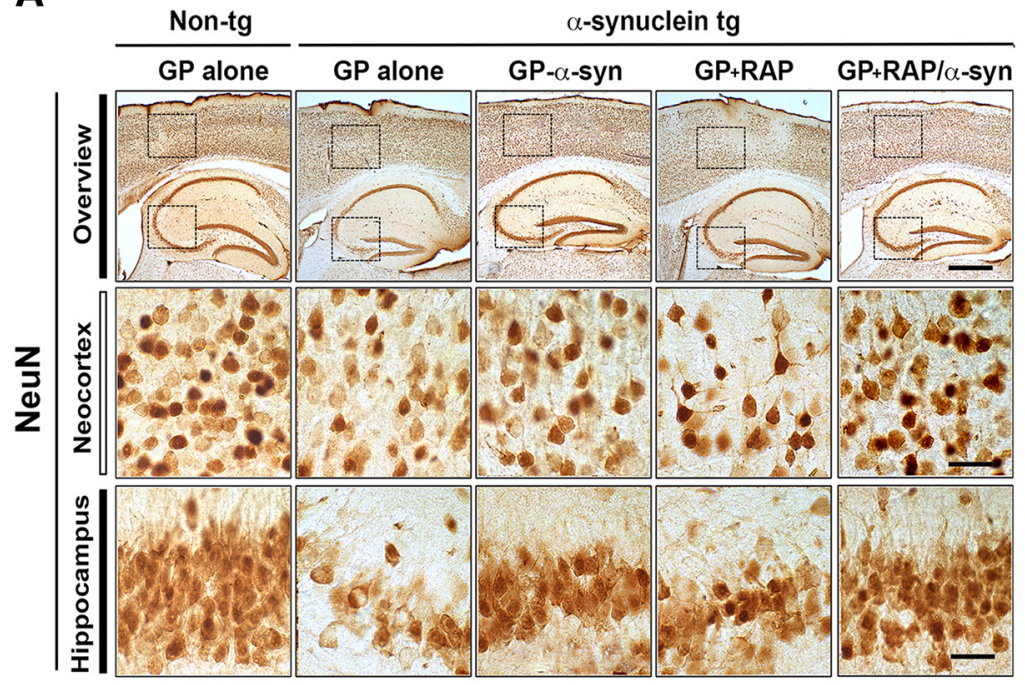

B

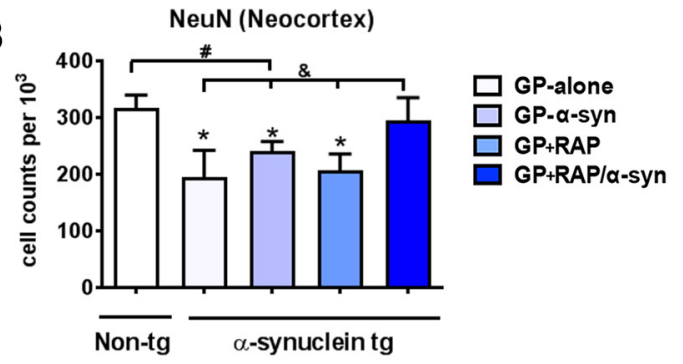

C

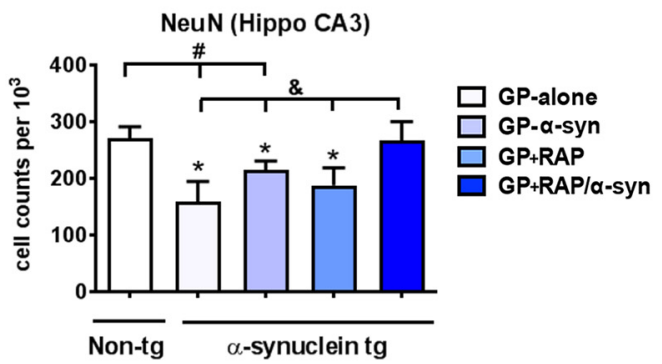

Figure 7. Effects of combined vaccination with GP $+\mathrm{RAP} / \alpha$-syn on neurodegeneration in the brains of $\alpha$-syn tg mice. Immunohistochemical analysis of neocortex and CA3 hippocampal brain sections from $\alpha$-syn tg mice immunized with GP, GP- $\alpha$-syn, GP + RAP, or GP + RAP/ $\alpha$-syn and non-tg control mice immunized with GP. Neuronal cells were visualized with an antibody against NeuN. $\boldsymbol{A}-\boldsymbol{C}$, Representative low- and high-magnification photomicrographs $(\boldsymbol{A})$ and computer-aided analysis of neocortex $(\boldsymbol{B})$ and $\mathrm{CA3}$ hippocampus $(\boldsymbol{C})$ immunostained with the neuronal antibody marker NeuN. Compared with non-tg mice treated with GP-alone, the $\alpha$-syn tg mice treated with GP-alone had a decreased number of NeuN-positive cells in the neocortex and CA3 of hippocampus; treatment with GP- $\alpha$-syn partially prevented the loss, while GP + RAP/ $\alpha$-syn treatment fully protected the mice againstneuronal loss. Scale bars:low-magnification, $250 \mu \mathrm{m} ;$ high-magnification, $50 \mu \mathrm{m}$. $p<$ 0.05 using ANOVA followed by Dunnett's post hoc test comparing each of the other groups with GP-alone treated non-tg mice (*), GP +RAP/ $\alpha$-syn (\&), or GP- $\alpha$-syn (\#) treatment. $N=6 /$ group.

and 0.0006 , respectively), as well as in the hippocampus of GPalone-treated $\alpha$-syn tg mice (Fig. 10C,D; $p=0.0001$ ). Moreover, in the neocortex, there was a significant increase in the number of activated microglia in $\alpha$-syn tg mice treated with GP-alone compared with non-tg mice (Fig. 10E,F; $p=0.0007$ ), which was significantly reduced by treatment with $\mathrm{GP}+\mathrm{RAP} / \alpha$-syn (Fig. $10 E, F ; p=0.0001)$. Similarly, the number of activated microglia was also increased in the hippocampus in $\alpha$-syn tg mice treated with GP-alone compared with non-tg mice (Fig. 10G,H; $p=$ 0.0001 ). The number of activated microglia was significantly re- 
A

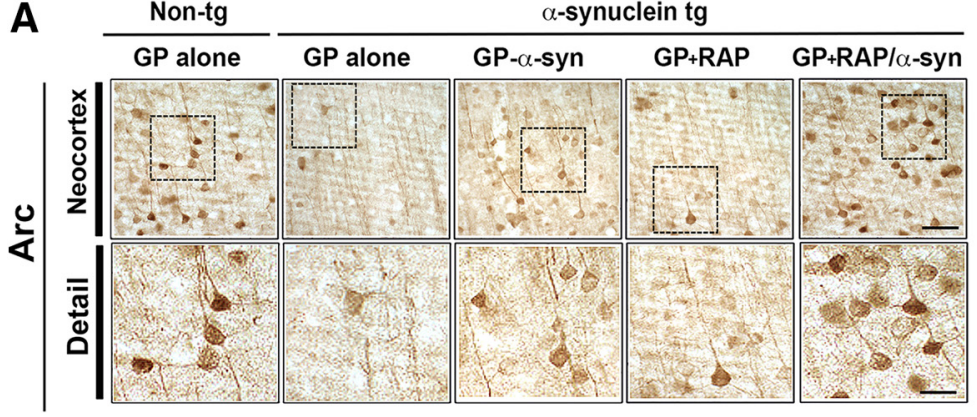

C

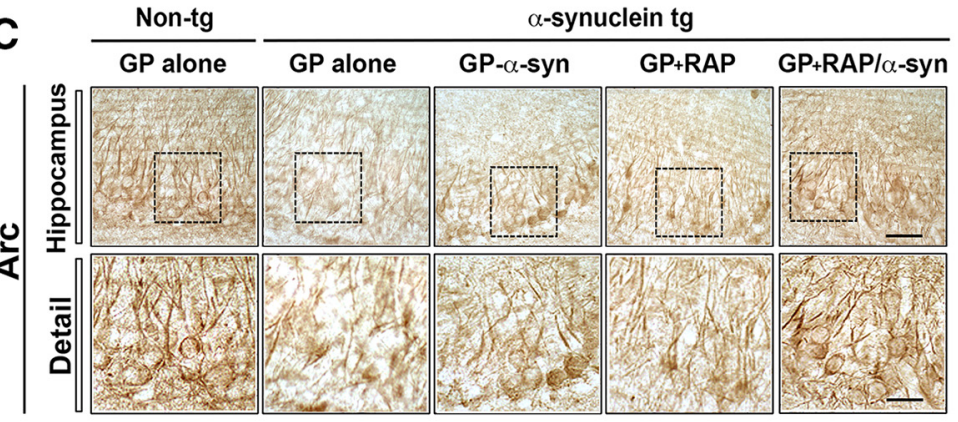

B

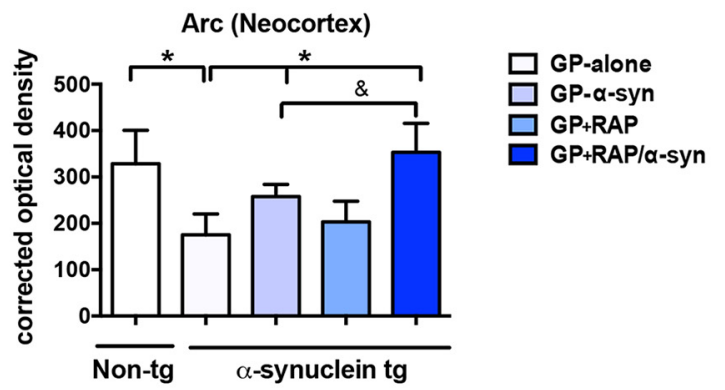

D

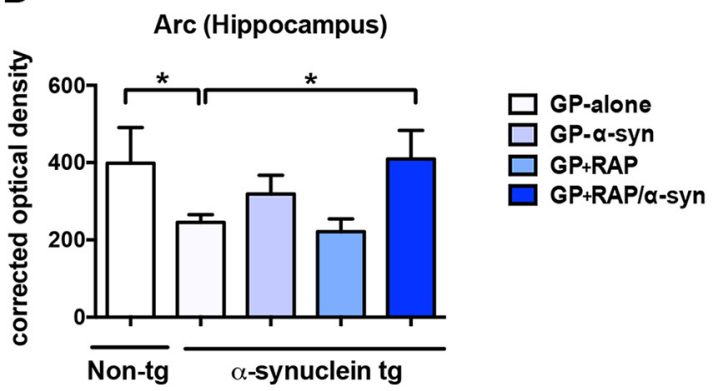

Figure 8. Effects of combined GP+RAP/ $\alpha$-syn vaccination on markers of neuronal activation. Immunocytochemical analysis of neocortex and CA3 hippocampal brain sections from $\alpha$-syn tg mice immunized with GP, GP- $\alpha$-syn, GP + RAP, or GP+RAP/ $\alpha$-syn and non-tg control mice immunized with GP. Activated neuronal cells were visualized with an antibody against Arc. $A, B$, Representative photomicrographs at low and high magnification from neocortex $(\boldsymbol{A})$ and quantitative analysis of neuronal activation $(\boldsymbol{B})$. $\boldsymbol{C}, \boldsymbol{D}$, Representative photomicrographs at low and high magnification from hippocampus $(\boldsymbol{C})$ and quantitative analysis of neuronal activation $(\boldsymbol{D})$. Compared with non-tg GP-alone, in the $\alpha$-syn tg mice treated with GP-alone there was a decrease in Arc-immunoreactivity in the neocortex and CA3 of hippocampus; treatment with GP- $\alpha$-syn partially increased neuronal activation, while treatment with GP $+\mathrm{RAP} / \alpha$-syn was more effective. $p<$ 0.05 using ANOVA followed by Dunnett's post hoc test comparing each of the other groups of tg mice treated with GP-alone $\left(^{*}\right)$ or GP + RAP $/ \alpha$-syn $(\&) . N=6$ mice $/$ group. Scale bars: lower magnification, $50 \mu \mathrm{m}$; detail, $10 \mu \mathrm{m}$.

A

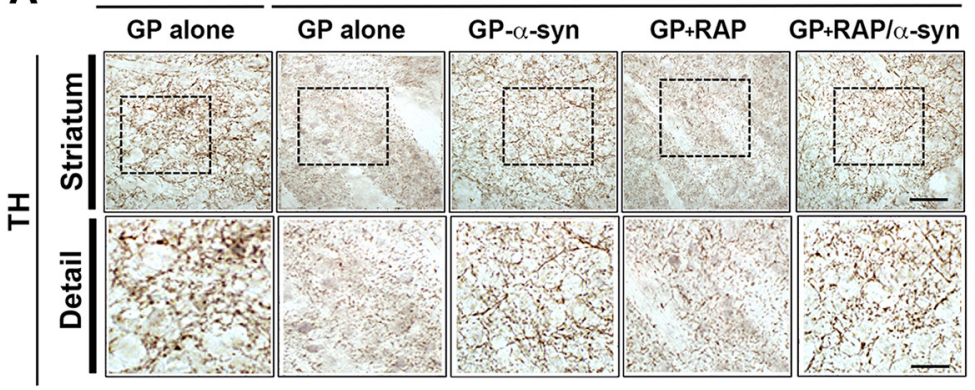

C

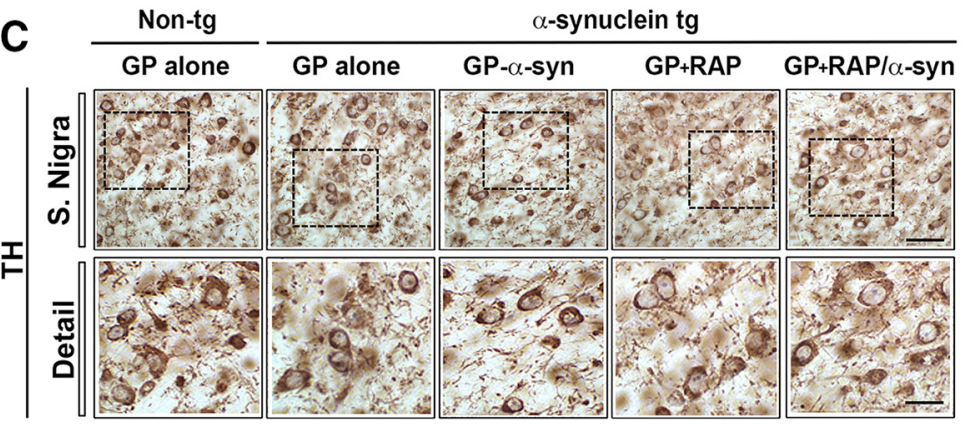

B

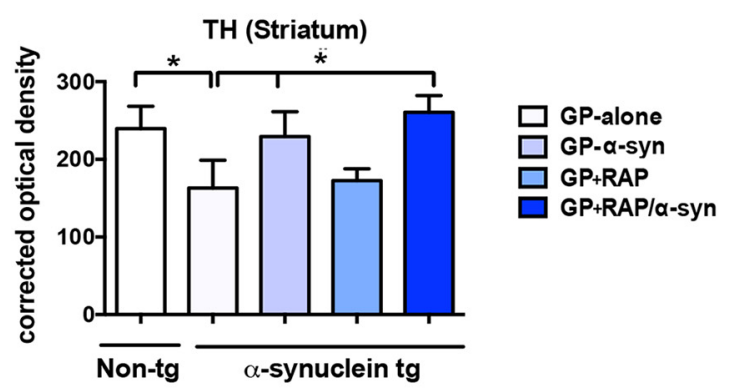

TH (S. Nigra)

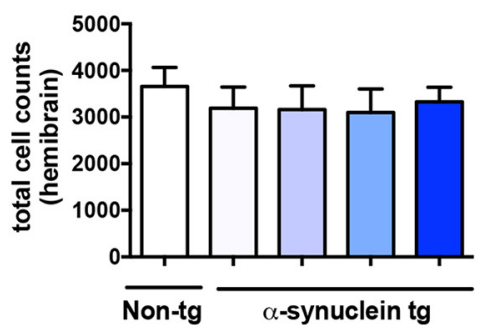

$\square$ GP-alone

$\square$ GP-a-syn

GP+RAP

GP+RAP/a-syn

Figure 9. Effects of combined GP+RAP/ $\alpha$-syn vaccination on the dopaminergic system in the brains of $\alpha$-syn tg mice. Immunocytochemical analysis of striatum and substantia nigra brain sections from $\alpha$-syn tg mice immunized with GP, GP- $\alpha$-syn, GP + RAP, or GP + RAP/ $\alpha$-syn and non-tg control mice immunized with GP. Dopaminergic cells were visualized with an antibody against TH. $\boldsymbol{A}, \boldsymbol{B}$, Representative photomicrographs at low and high magnification from striatum $(\boldsymbol{A})$ and quantitative analysis of the corrected OD of TH-positive cells $(\boldsymbol{B})$. $\boldsymbol{C}, \boldsymbol{D}$, Representative photomicrographs at low and high magnification from the substantia nigra ( $($ ) and quantitative analysis of the $0 \mathrm{D}$ of TH-positive cells (D). Compared with treatment of non-tg mice with GP-alone, in $\alpha$-syn tg mice treated with GP-alone there was a decrease in TH immunoreactivity in the striatum. Treatment with GP $+\alpha$-syn and GP $+\mathrm{RAP} / \alpha$-syn significantly increased TH immunoreactivity compared with treatment with GP-alone in $\alpha$-syn tg mice. There were no significant changes in TH immunoreactivity in the substantia nigra. $p<0.05$ using ANOVA followed by Dunnett's post hoc test comparing each of the other groups with tg mice treated with GP-alone $\left(^{*}\right) . N=6$ mice per group. Scale bars: lower magnification, $50 \mu \mathrm{m}$; detail, $10 \mu \mathrm{m}$. 
A

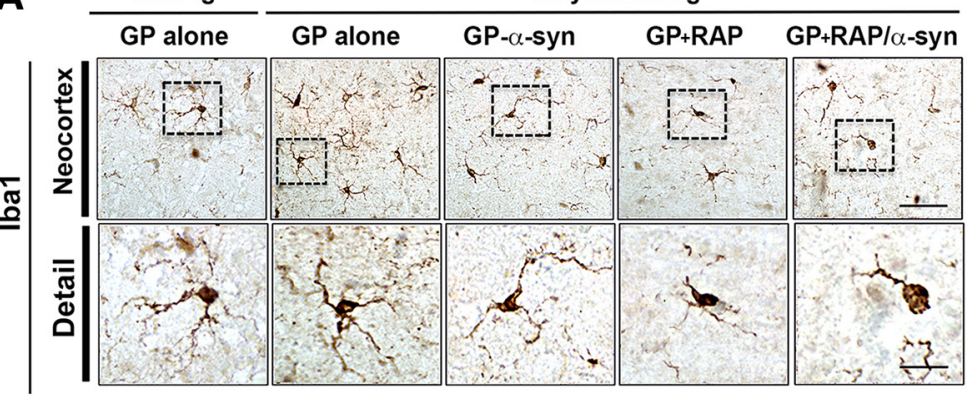

C
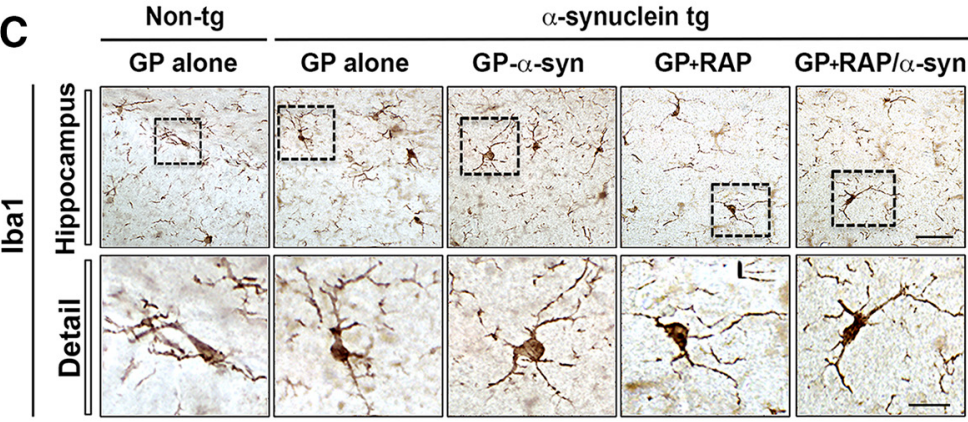

$\mathbf{E}$

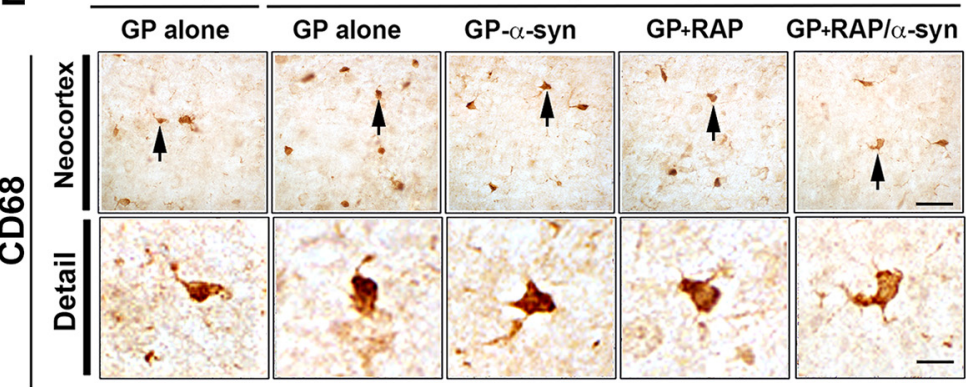

G

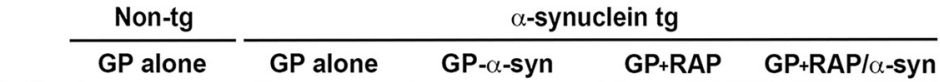

○ั

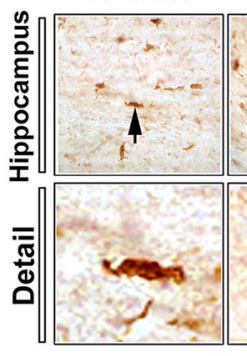

B

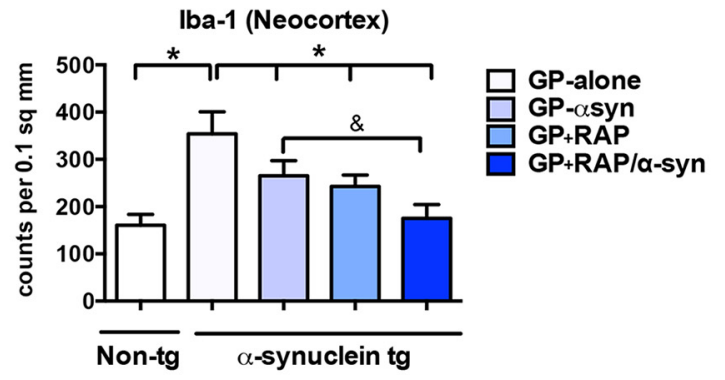

D

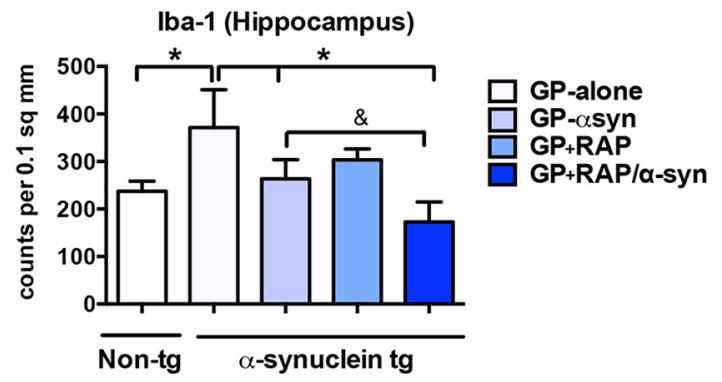

$\mathbf{F}$

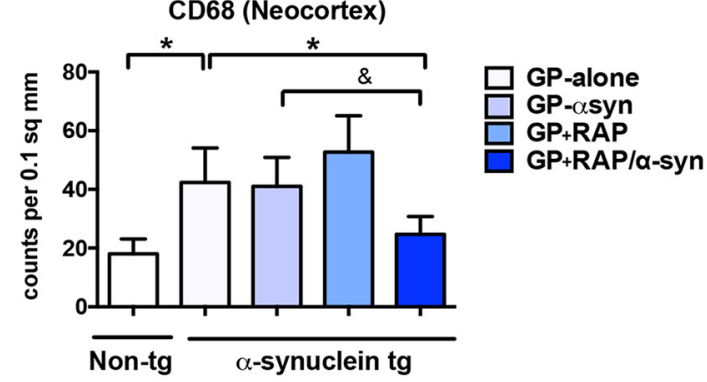

$\mathbf{H}$

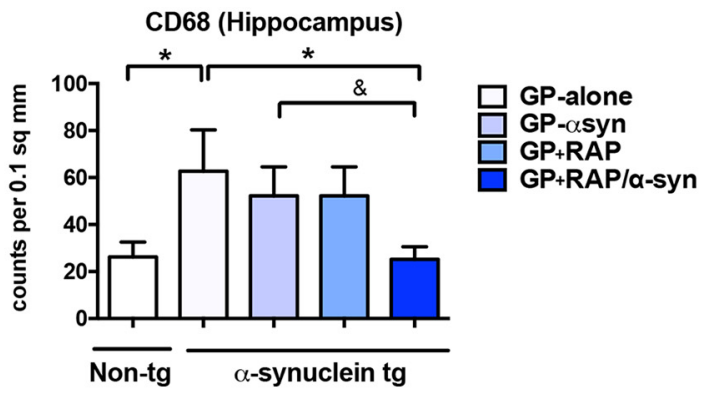

Figure 10. Effects of combined GP+RAP/ $\alpha$-syn vaccination on microglial cell markers in the brains of $\alpha$-syn tg mice. Immunocytochemical analysis of neocortex and CA3 hippocampal brain sections from $\alpha$-syn tg mice immunized with GP, GP- $\alpha$-syn, GP + RAP, or GP + RAP/ $\alpha$-syn and non-tg control mice immunized with GP. Microglial cells were visualized with an antibody against Iba1. $\boldsymbol{A}, \boldsymbol{B}$, Representative photomicrographs at low and high magnification from neocortex $(\boldsymbol{A})$ and quantitative analysis of the number of immunoreactive microglia per $0.1 \mathrm{~mm}^{2}(\boldsymbol{B})$. C, $\boldsymbol{D}$, Representative photomicrographs at low and high magnification from hippocampus $(\boldsymbol{C})$ and quantitative analysis of the number of immunoreactive microglia per $0.1 \mathrm{~mm}{ }^{2}(D)$. Compared with non-tg mice treated with GP-alone, in the $\alpha$-syn tg mice treated with GP-alone there were increased numbers of Iba ${ }^{+}{ }^{+}$cells in the neocortex and CA3 of hippocampus; treatment with GP- $\alpha$-syn and GP+RAP partially reduced the microglial cell number, while treatment with GP+RAP/ $\alpha$-syn was more effective. $E$, $\boldsymbol{F}$, Representative photomicrographs at low and high magnification from neocortex $(\boldsymbol{E})$ and quantitative analysis of the number of $\mathrm{CD} 68$-immunoreactive cells per $0.1 \mathrm{~mm}^{2}(\boldsymbol{F}) . \boldsymbol{G}, \boldsymbol{H}$, Representative photomicrographs at low and high magnification from hippocampus $(\boldsymbol{G})$ and quantitative analysis of the number of CD68-immunoreactive cells per $0.1 \mathrm{~mm}^{2}(\boldsymbol{H})$. Scale bars: low magnification, $50 \mu \mathrm{m}$; high magnification, $10 \mu \mathrm{m} . p<0.05$ using ANOVA followed by Dunnett's post hoc test comparing each of the other groups with tg mice treated with GP-alone $(*)$ or GP + RAP $/ \alpha$-syn $(\&) . N=6$ mice/group.

duced by GP+RAP/ $\alpha$-syn treatment (Fig. 10G,H; $p=0.0001$ ). Further investigation revealed a significant increase in the colocalization between $\alpha$-syn and microglia in $\alpha$-syn tg mice treated with GP-alone compared to non-tg mice (Fig. 11; $p=$ $0.0001)$. Treatment with either GP $+\alpha$-syn or GP $+\mathrm{RAP} / \alpha$-syn significantly increased the percentage of colocalization between microglia and $\alpha$-syn, suggesting increased clearance of $\alpha$-syn with these treatments (Fig. 11; $p$ values $=0.0001$ and 0.0001 , respectively). Likewise, when compared with non-tg mice, $\alpha$-syn tg mice treated with GP-alone displayed increased astrogliosis in 


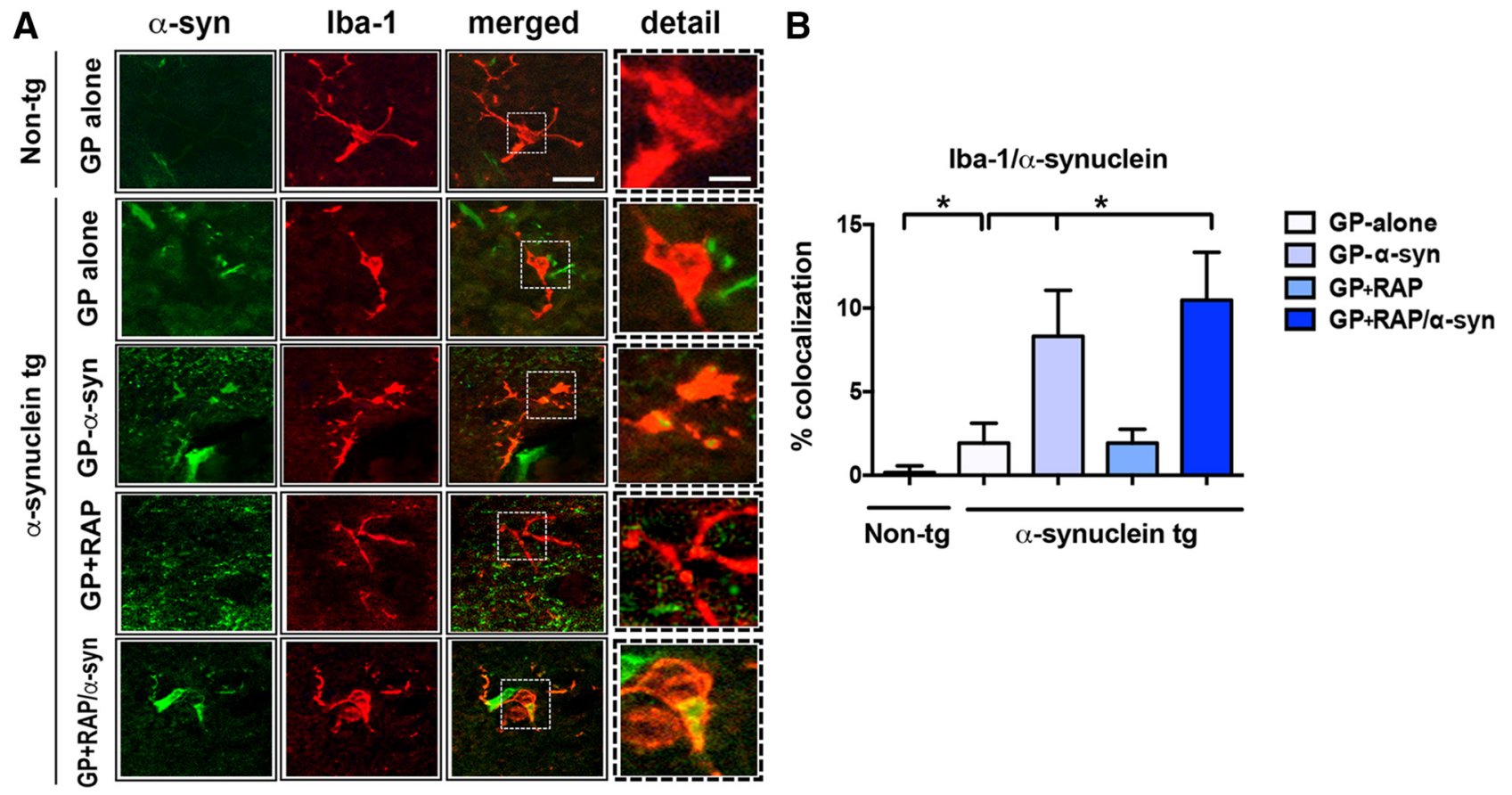

Figure 11. Effects of combined vaccination with GP + RAP $/ \alpha$-syn on microglial cell clearance of $\alpha$-syn in the brains of $\alpha$-syn tg mice. Confocal analysis of neocortex brain sections from $\alpha$-syn $\operatorname{tg}$ mice immunized with GP, GP- $\alpha$-syn, GP + RAP, or GP + RAP/ $\alpha$-syn and non-tg control mice immunized with GP. $\boldsymbol{A}, \boldsymbol{B}$, Representative images of the colocalization $(\boldsymbol{A})$ and quantification $(\boldsymbol{B})$ of $\alpha$-syn (green channel) and microglial cells, which were visualized with an antibody against lba-1 (red channel). The percentage of colocalization of $\alpha$-syn and microglia was significantly increased in $\alpha$-syn tg mice treated with GP-alone compared with non-tg mice. In the $\alpha$-syn tg mice, treatment with GP $+\alpha$-syn and GP + RAP/ $\alpha$-syn significantly increased the amount of colocalization between $\alpha$-syn and microglia compared with GP-alone. $p<0.05$ using ANOVA followed by Dunnett's post hoc test comparing treatment with GP-alone in $\alpha$-syn tg mice $(*) . N=6$ mice/group. Scale bars: merged image, $15 \mu \mathrm{m}$; detail, $5 \mu \mathrm{m}$.

A

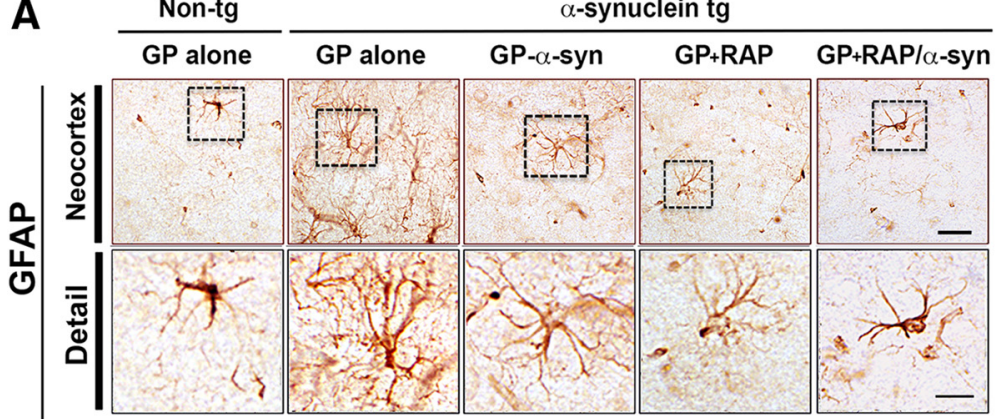

c
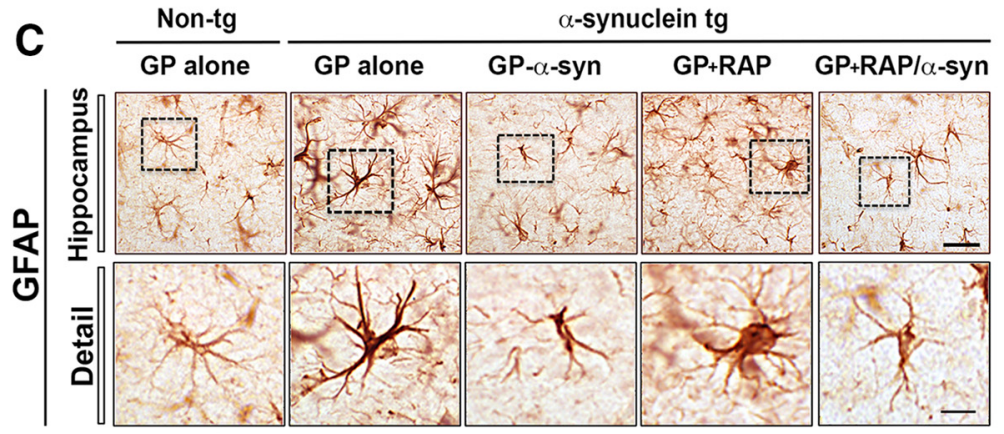

B

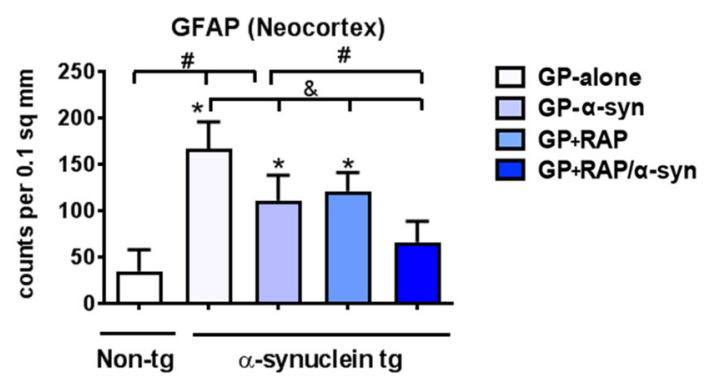

D

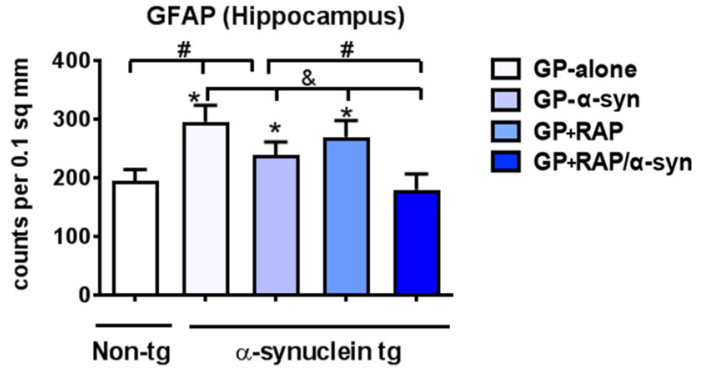

Figure 12. Effects of combined vaccination with GP + RAP/ $\alpha$-syn on astroglial cells in the brains of $\alpha$-syn tg mice. Immunohistochemical analysis of neocortex and CA3 hippocampal brain sections from $\alpha$-syn tg mice immunized with GP, GP- $\alpha$-syn, GP + RAP, or GP+RAP/ $\alpha$-syn and non-tg control mice immunized with GP. Astroglial cells were visualized with an antibody against GFAP. $\boldsymbol{A}, \boldsymbol{B}$, Representative photomicrographs at low and high magnification from neocortex $(\boldsymbol{A})$ and quantitative analysis of the number of immunoreactive microglia per $0.1 \mathrm{~mm}^{2}(\boldsymbol{B})$. $\boldsymbol{C}, \boldsymbol{D}$, Representative photomicrographs at low and high magnification from hippocampus $(\boldsymbol{C})$ and quantitative analysis of the number of immunoreactive astroglia per $0.1 \mathrm{~mm}{ }^{2}(\boldsymbol{D})$. Compared with non-tg mice treated with GP-alone, in the $\alpha$-syn tg mice treated with GP-alone there was an increase in astrogliosis in the neocortex and CA3 of the hippocampus, and treatment with GP- $\alpha$-syn and GP/RAP partially re-established the astroglial cell immunostaining, while GP + RAP $/ \alpha$-syn was more effective. Scale bars: low magnification, $25 \mu \mathrm{m}$; high magnification, $10 \mu \mathrm{m}$. $p<0.05$ using ANOVA followed by Dunnett's post hoc test comparing each of the other groups with non-tg mice treated with GP-alone $(*), G P+R A P / \alpha$-syn $(\&)$, or GP- $\alpha$-syn (\#). N $=6$ mice/group. 
A

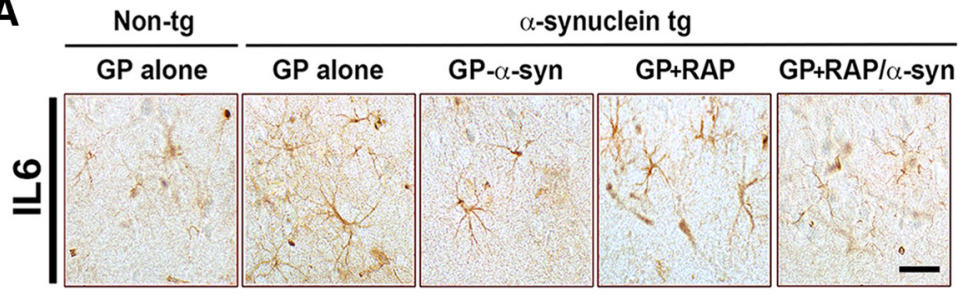

C
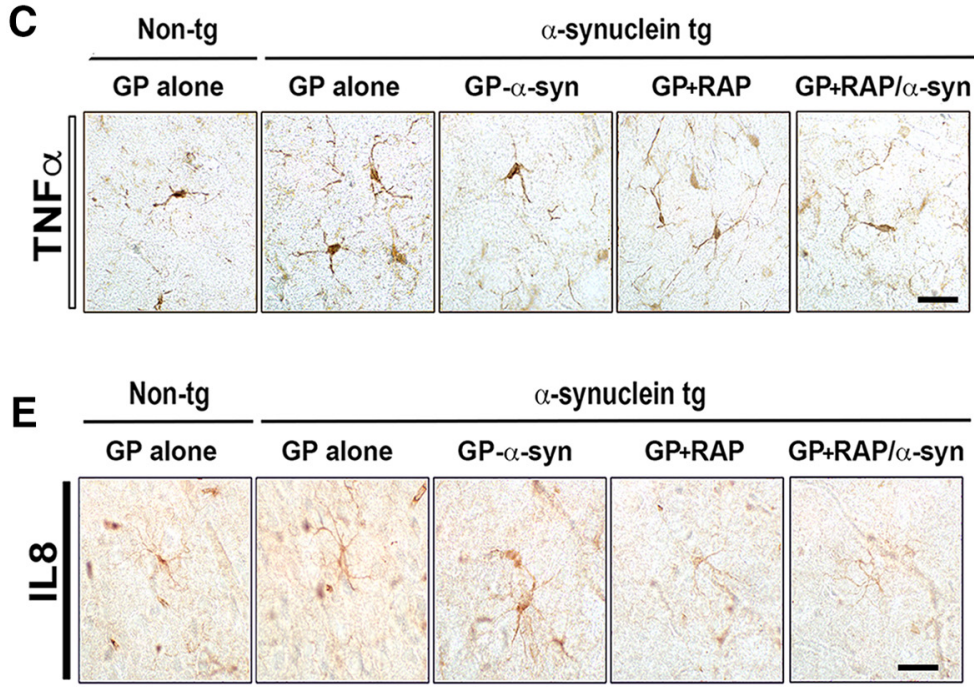

G

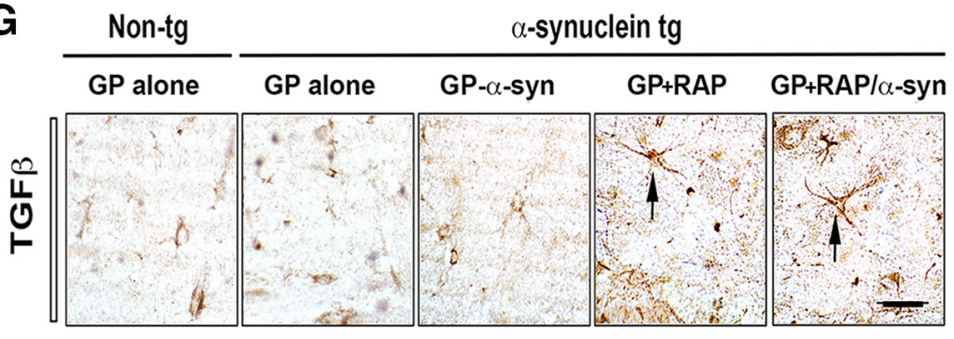

I

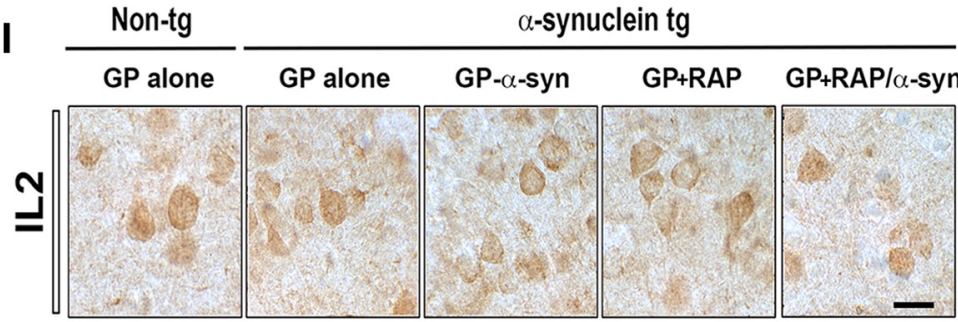

B

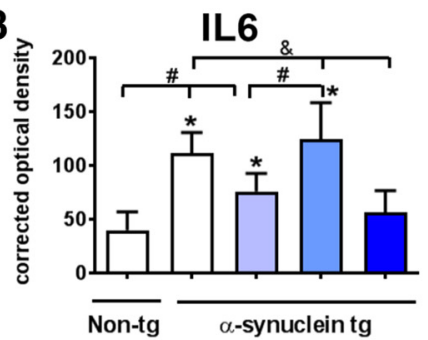

D

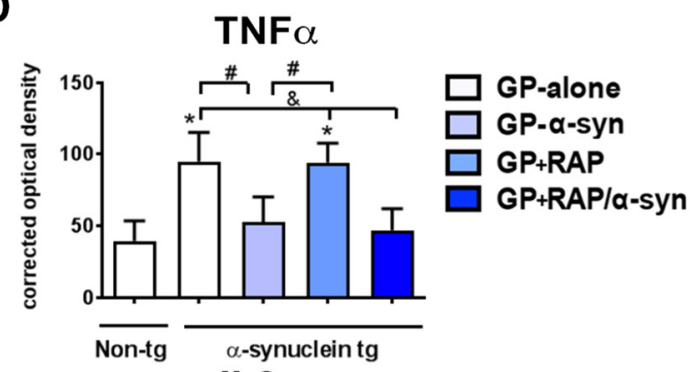

$\mathbf{F}$

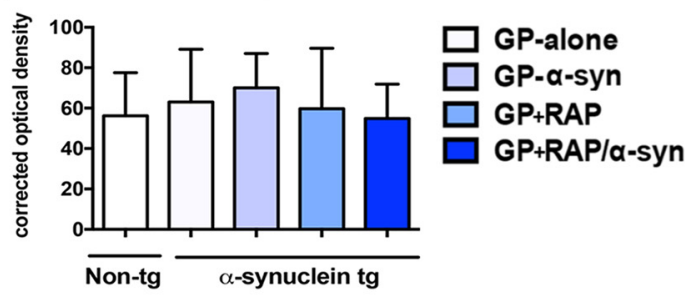

H

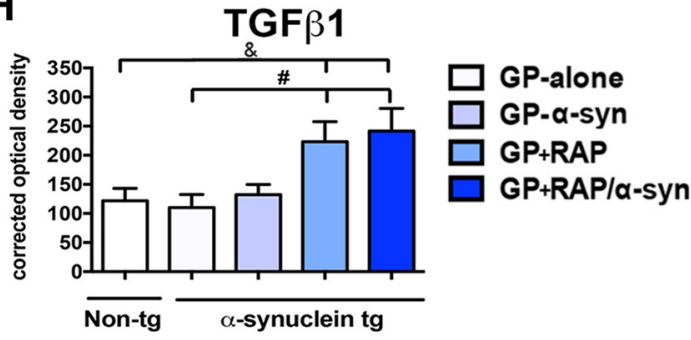

J

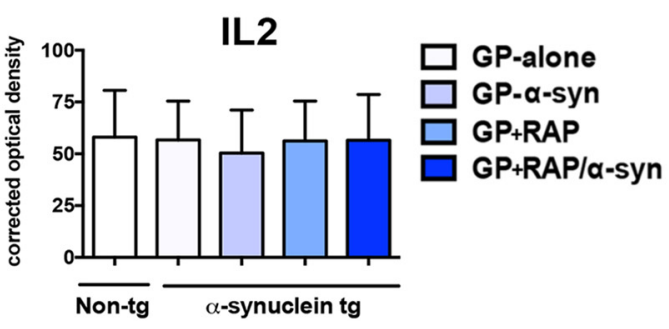

Figure 13. Effects of combined vaccination with GP+RAP/ $\alpha$-syn on cytokines in the brains of $\alpha$-syn tg mice. Immunohistochemical analysis of neocortex brain sections from $\alpha$-syn tg mice immunized with GP, GP- $\alpha$-syn, GP + RAP, or GP + RAP/ $\alpha$-syn and non-tg control mice immunized with GP. Proinflammatory cytokine immunoreactivity was visualized with antibodies against IL-6, TNF- $\alpha$, and IL-8, and the immunomodulator cytokine levels visualized with antibodies against TGF- $\beta 1$ and IL-2. A, Representative photomicrographs and quantification of IL-6 $(\boldsymbol{A}, \boldsymbol{B})$, TNF- $\alpha(\boldsymbol{C}, \boldsymbol{D})$, IL-8 $(\boldsymbol{E}, \boldsymbol{F})$, TGF- $\beta 1(\boldsymbol{G}, \boldsymbol{H})$, and IL-2 $(\boldsymbol{I}, \boldsymbol{J})$ immunoreactivity. Scale bar, $25 \mu \mathrm{m} . p<0.05$ using ANOVA followed by Dunnett's post hoc test comparing each of the other groups with non-tg mice treated with GP-alone $(*), G P+R A P / \alpha$-syn (\&), or GP- $\alpha$-syn (\#). $N=6$ mice/group.

the neocortex (Fig. 12A,B; $p=0.0001$ ) and hippocampus (Fig. $12 C, D ; p=0.0001$ ). Astrocytosis (Fig. 12) was similarly decreased with GP- $\alpha$-syn and GP + RAP/ $\alpha$-syn treatment both in the neocortex (Fig. $12 A, B ; p=0.0020$ and 0.0001 , respectively) and hippocampus (Fig. $12 C, D ; p=0.0024$ and 0.0001 , respectively). Interestingly, $\mathrm{GP}+\mathrm{RAP} / \alpha$-syn treatment resulted in a greater reduction in microgliosis in both the neocortex and hippocampus (Fig. $10 B, D ; p=0.0002$ and 0.0081 , respectively) and astrocytosis (Fig. 12B,D; $p=0.0134$ and 0.0016 , respectively) compared with GP- $\alpha$-syn treatment.
Next, we analyzed the effects of GP vaccination on levels of proinflammatory cytokines IL-6, TNF- $\alpha$, and IL-8. Compared with non-tg mice, $\alpha$-syn tg mice treated with GP-alone displayed increased levels of IL-6 (Fig. 13A, $B ; p=0.0001$ ) and TNF- $\alpha$ immunoreactivity (Fig. $13 C, D, p=0.0001$ ). Treatment with GP$\alpha$-syn and GP $+\mathrm{RAP} / \alpha$-syn resulted in decreased IL-6 (Fig. $13 A, B ; p=0.0384$ and 0.0010 , respectively) and TNF- $\alpha$ (Fig. $13 C, D ; p=0.0006$ and 0.0001$)$ compared with $\alpha$-syn tg mice treated with GP-alone. No significant differences or effects of GP vaccination were detected among the groups when analyzing IL-8 


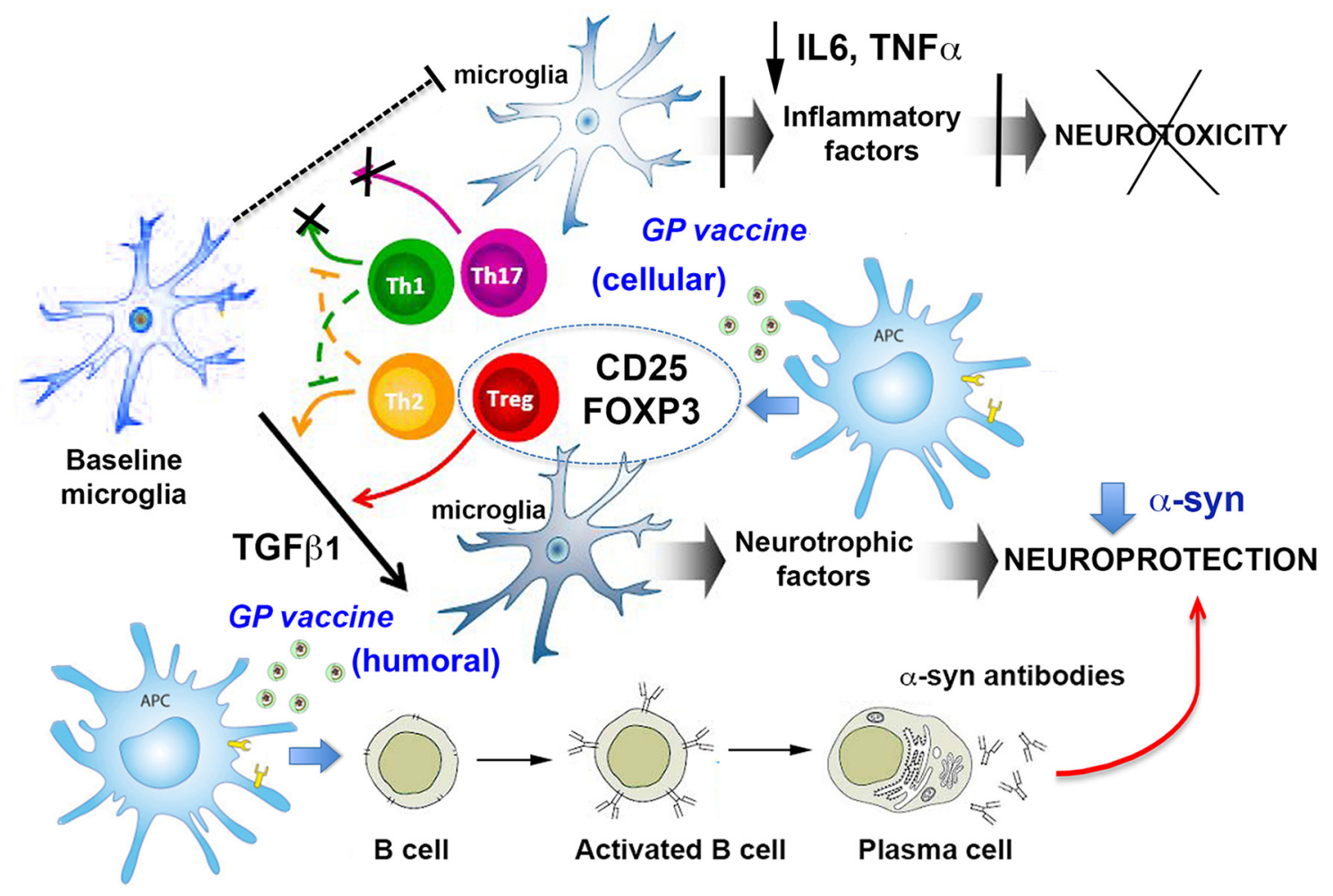

Figure 14. Diagrammatic representation of the potential mechanisms through which combined active and cellular vaccine with GP $+\mathrm{RAP} / \alpha$-syn might work. We propose that vaccination with $\mathrm{GP}+\mathrm{RAP} / \alpha$-syn elicits both humoral and cellular responses that are neuroprotective. The GP $+\mathrm{RAP} / \alpha$-syn is internalized by antigen presenting cells (APCs), which in turn cross talk with plasma cells and Tregs to produce, respectively, anti- $\alpha$-syn antibodies and immunomodulatory cytokines (TGF- $\beta 1$ ), which in turn switch microglia into a neuroprotective phenotype.

levels of immunoreactivity (Fig. 13E,F). Consistent with these results, immunoblot analysis showed that GP- $\alpha$-syn, GP+RAP, and $\mathrm{GP}+\mathrm{RAP} / \alpha$-syn treatment also led to a reduction in TNF- $\alpha$ compared with $\alpha$-syn tg mice treated with GP-alone (Fig. $4 A, E ; p$ value for each comparison $=0.0001)$ and IL-6 (Fig. $4 A, F$; $p$ value for each comparison $=0.0001$ ).

To understand the mechanisms by which GP vaccine may reduce inflammatory response levels of immunomodulatory cytokines, TGF- $\beta 1$ and IL- 2 were analyzed. Levels of TGF- $\beta 1$ were similar between the non-tg and the $\alpha$-syn tg mice treated with GP-alone or GP- $\alpha$-syn (Fig. 13G,H). However, treatment with $\mathrm{GP}+\mathrm{RAP}(p=0.0001$ for each comparison $)$ and $\mathrm{GP}+\mathrm{RAP} / \alpha-$ syn $(p=0.0001$ for each comparison $)$ resulted in increased levels of TGF- $\beta 1$ immunoreactivity in the tg mice (Fig. $13 G, H$ ) compared with both non-tg and tg mice treated with GP-alone. No significant effects of the GP vaccination or with GP $+\alpha$-syn treatment were detected among the groups when analyzing levels of IL-2 immunoreactivity (Fig. 13I,J). Consistent with these results, immunoblot analysis showed that treatment with GP+RAP and GP+RAP/ $\alpha$-syn similarly resulted in increased levels of TGF- $\beta 1$ in the $\alpha$-syn tg mice compared with treatment with GP-alone in either the non-tg or $\alpha$-syn tg mice (Fig. 4A, $G ; p=0.0001$ for each comparison).

Together, these results suggest that GP vaccines containing RAP triggered increased expression of TGF- $\beta 1$, which in turn promoted retention of Tregs in the CNS that might regulate and hamper microglial and astroglial proinflammatory responses and decrease the expression of IL- 6 and TNF- $\alpha$ (Fig. 14). This, in combination with the production of anti- $\alpha$-syn antibodies, resulted in a potentially more effective vaccine compared with GP$\alpha$-syn alone (Fig. 14).

\section{Discussion}

Our study shows that vaccination with GP $+\mathrm{RAP} / \alpha$-syn can elicit the production of high titers of anti- $\alpha$-syn antibodies in combination with an anti-inflammatory cellular response mediated by TGF- $\beta 1$-produced by iTreg (CD25 and FOXP ${ }^{+}$) cells in the CNS. We found that these effects were associated with greater attenuation of microglial and astroglial neuroinflammatory responses, as well as a complete amelioration of neuronal loss in an $\alpha$-syn tg mouse model of DLB when compared with GP- $\alpha$-syn alone. Moreover, vaccination with $\mathrm{GP}+\mathrm{RAP} / \alpha$-syn resulted in reduced accumulation of $\alpha$-syn and microglia-mediated clearance of $\alpha$-syn comparable to the effects observed when vaccinating tg mice with GP- $\alpha$-syn alone.

For these experiments, we chose to use the PDGF- $\alpha$-syn tg mice (Masliah et al., 2000) because these animals display a widespread accumulation of $\alpha$-syn in neuronal cells in the deeper layers of the neocortex and hippocampus (CA2-3) mimicking some aspects of DLB (Amschl et al., 2013; Adamowicz et al., 2017). We have also shown in independent studies that these mice have high titers of anti- $\alpha$-syn antibody upon vaccination with $\alpha$-syn peptides with trafficking of antibodies into the CNS and target engagement of the $\alpha$-syn aggregates in the neocortex and limbic system (Masliah et al., 2005; Mandler et al., 2014).

In previous studies, mice were vaccinated with recombinant $\alpha$-syn or with peptides mimicking the antigenicity of $\alpha$-syn that resulted in the production of antibodies that recognized the $\mathrm{C}$ terminus of $\alpha$-syn and partially blocked neuroinflammation and neurodegeneration (Masliah et al., 2005; Mandler et al., 2014). The difference between these previous studies and the data we present here is that we immunized with GP+RAP/ $\alpha$-syn, which 
triggered a robust anti- $\alpha$-syn humoral response and promoted the formation of iTregs in the CNS. In combination, these iTregs were more effective at modulating neuroinflammatory responses and ameliorating the neurodegenerative pathology in the neocortex and hippocampus, than upon immunization with the antigen alone. Regulatory T cells are potent suppressors, playing important roles in autoimmunity and transplantation tolerance (Fu et al., 2004), which can be classified as iTreg or natural Treg. In the CNS, Tregs have been studied mostly in the context of autoimmunity (e.g., multiple sclerosis) and persistent viral infection in the CNS (e.g., HIV-1; Reuter et al., 2012), but less is known about their role in neurodegeneration and neurotherapeutics. For example, recent studies have shown that manipulation of Tregs can be used to regulate virus-specific $\mathrm{CD} 8{ }^{+}$effector $\mathrm{T}$ cells and virus persistence in the brain (Reuter et al., 2012). It has been reported that Tregs induce neuroprotective immune responses in murine models of stroke, amyotrophic lateral sclerosis, and HIV-1-associated neurocognitive disorders (Reynolds et al., 2009).

Moreover, previous studies have shown that iTregs can be neuroprotective in a neurotoxin-induced model of PD (Reynolds et al., 2007) by modulating T-helper cell type 17 responses (Reynolds et al., 2010). For those experiments, adoptive transfer of T cells was performed by administering copolymer- 1 to mice challenged with the nigrostriatal toxin 1-methyl-4-phenyl-1,2,3,6tetrahydropyridine (MPTP; Reynolds et al., 2010). iTregs were found to mediate neuroprotection in the MPTP-challenged mice by reducing microglial responses to stimuli, including aggregated, nitrated $\alpha$-syn. In addition, iTreg-mediated neuroprotection was functional upon removal of iTregs from culture before stimulation (Reynolds et al., 2010).

It has been reported recently that the codelivery of an antigen plus RAP in nanoparticles induced Tregs (Maldonado et al., 2015). We adapted this immunization strategy to $\alpha$-syn using the antigen-presenting cell GP vaccine delivery system to test the hypothesis that combining humoral and immunosuppressive cellular immunization would synergize to enhance $\alpha$-syn clearance and reduce inflammation and neuropathological symptoms. The mechanisms through which the GP $+\mathrm{RAP} / \alpha$-syn vaccine might work probably involve several mechanisms (Fig. 14). We propose that, in addition to the effects of the antibodies, the GP+RAP vaccine might trigger iTregs to produce TGF- $\beta 1$, which in turn might mediate the conversion of microglial cells into a neuroprotective state (Fig. 14). Recent reports suggest a role for TGF- $\beta 1$ in the generation of iTregs from $\mathrm{CD} 4{ }^{+} \mathrm{CD} 25^{-}$precursors, and recent studies have shown that TGF- $\beta 1$ triggers FOXP 3 expression in $\mathrm{CD} 4{ }^{+} \mathrm{CD} 25^{-}$precursors and that these FOXP ${ }^{+}$cells act like conventional Tregs. The generation of FOXP3 ${ }^{+}$iTregs requires stimulation of the T-cell receptor, the IL-2 receptor, and the TGF- $\beta 1$ receptors (Fu et al., 2004). In this context, it is worth mentioning that while vaccination with both GP+RAP or $\mathrm{GP}+\mathrm{RAP} / \alpha$-syn induced a Treg cell response, only the GP+RAP/ $\alpha$-syn vaccine combination was effective in reducing $\alpha$-syn accumulation, and neurodegenerative and inflammatory pathology. In summary, we have shown that a novel vaccination modality based on GP-RAP/ $\alpha$-syn is capable of triggering both neuroprotective humoral and iTreg responses in mouse models of synucleinopathy and that the combined vaccine is more effective than either humoral or cellular immunization alone. Together, these results support the further development of this multifunctional vaccine approach for the treatment of synucleinopathies such as PD, DLB, and Multiple System Atrophy.

\section{References}

Adamowicz DH, Roy S, Salmon DP, Galasko DR, Hansen LA, Masliah E, Gage FH (2017) Hippocampal $\alpha$-synuclein in dementia with Lewy bodies contributes to memory impairment and is consistent with spread of pathology. J Neurosci 37:1675-1684. CrossRef Medline

Amschl D, Neddens J, Havas D, Flunkert S, Rabl R, Römer H, Rockenstein E, Masliah E, Windisch M, Hutter-Paier B (2013) Time course and progression of wild type alpha-synuclein accumulation in a transgenic mouse model. BMC Neurosci 14:6. CrossRef Medline

Bae EJ, Lee HJ, Rockenstein E, Ho DH, Park EB, Yang NY, Desplats P, Masliah E, Lee SJ (2012) Antibody-aided clearance of extracellular $\alpha$-synuclein prevents cell-to-cell aggregate transmission. J Neurosci 32:13454-13469. CrossRef Medline

Brody DL, Holtzman DM (2008) Active and passive immunotherapy for neurodegenerative disorders. Annu Rev Neurosci 31:175-193. CrossRef Medline

Cole GT, Hung CY, Sanderson SD, Hurtgen BJ, Wüthrich M, Klein BS, Deepe GS, Ostroff GR, Levitz SM (2013) Novel strategies to enhance vaccine immunity against coccidioidomycosis. PLoS Pathog 9:e1003768. CrossRef Medline

Dickson DW, Liu W, Hardy J, Farrer M, Mehta N, Uitti R, Mark M, Zimmerman T, Golbe L, Sage J, Sima A, D'Amato C, Albin R, Gilman S, Yen SH (1999) Widespread alterations of alpha-synuclein in multiple system atrophy. Am J Pathol 155:1241-1251. CrossRef Medline

Fu S, Zhang N, Yopp AC, Chen D, Mao M, Chen D, Zhang H, Ding Y, Bromberg JS (2004) TGF-beta induces Foxp3 + T-regulatory cells from CD4 + CD25 - precursors. Am J Transplant 4:1614-1627. CrossRef Medline

Galvin JE, Lee VM, Trojanowski JQ (2001) Synucleinopathies: clinical and pathological implications. Arch Neurol 58:186-190. CrossRef Medline

Games D, Seubert P, Rockenstein E, Patrick C, Trejo M, Ubhi K, Ettle B, Ghassemiam M, Barbour R, Schenk D, Nuber S, Masliah E (2013) Axonopathy in an alpha-synuclein transgenic model of Lewy body disease is associated with extensive accumulation of C-terminal-truncated alphasynuclein. Am J Pathol 182:940-953. CrossRef Medline

Games D, Valera E, Spencer B, Rockenstein E, Mante M, Adame A, Patrick C, Ubhi K, Nuber S, Sacayon P, Zago W, Seubert P, Barbour R, Schenk D, Masliah E (2014) Reducing C-terminal-truncated $\alpha$-synuclein by immunotherapy attenuates neurodegeneration and propagation in Parkinson's disease-like models. J Neurosci 34:9441-9454. CrossRef Medline

Hartman ML, Kornfeld H (2011) Interactions between naive and infected macrophages reduce Mycobacterium tuberculosis viability. PLoS One 6:e27972. CrossRef Medline

Huang H, Ostroff GR, Lee CK, Wang JP, Specht CA, Levitz SM (2009) Distinct patterns of dendritic cell cytokine release stimulated by fungal beta-glucans and toll-like receptor agonists. Infect Immun 77:17741781. CrossRef Medline

Huang H, Ostroff GR, Lee CK, Specht CA, Levitz SM (2010) Robust stimulation of humoral and cellular immune responses following vaccination with antigen-loaded beta-glucan particles. MBio 1:e00164-10. CrossRef Medline

Huang H, Ostroff GR, Lee CK, Specht CA, Levitz SM (2013) Characterization and optimization of the glucan particle-based vaccine platform. Clin Vaccine Immunol 20:1585-1591. CrossRef Medline

Hurtgen BJ, Hung CY, Ostroff GR, Levitz SM, Cole GT (2012) Construction and evaluation of a novel recombinant $\mathrm{T}$ cell epitope-based vaccine against coccidioidomycosis. Infect Immun 80:3960-3974. CrossRef Medline

Iqbal K, Liu F, Gong CX (2016) Tau and neurodegenerative disease: the story so far. Nat Rev Neurol 12:15-27. CrossRef Medline

Jagannath C, Bakhru P (2012) Rapamycin-induced enhancement of vaccine efficacy in mice. Methods Mol Biol 821:295-303. CrossRef Medline

Jankovic J (2008) Parkinson's disease: clinical features and diagnosis. J Neurol Neurosurg Psychiatry 79:368-376. CrossRef Medline

Junn E, Lee KW, Jeong BS, Chan TW, Im JY, Mouradian MM (2009) Repression of alpha-synuclein expression and toxicity by microRNA-7. Proc Natl Acad Sci U S A 106:13052-13057. CrossRef Medline

Keating R, Hertz T, Wehenkel M, Harris TL, Edwards BA, McClaren JL, Brown SA, Surman S, Wilson ZS, Bradley P, Hurwitz J, Chi H, Doherty PC, Thomas PG, McGargill MA (2013) The kinase mTOR modulates the antibody response to provide cross-protective immunity to lethal infection with influenza virus. Nat Immunol 14:1266-1276. CrossRef Medline

Lashuel HA, Overk CR, Oueslati A, Masliah E (2013) The many faces of 
alpha-synuclein: from structure and toxicity to therapeutic target. Nat Rev Neurosci 14:38-48. CrossRef Medline

Laurie C, Reynolds A, Coskun O, Bowman E, Gendelman HE, Mosley RL (2007) CD4 + T cells from Copolymer-1 immunized mice protect dopaminergic neurons in the 1-methyl-4-phenyl-1,2,3,6-tetrahydropyridine model of Parkinson's disease. J Neuroimmunol 183:60-68. CrossRef Medline

Lee HJ, Suk JE, Patrick C, Bae EJ, Cho JH, Rho S, Hwang D, Masliah E, Lee SJ (2010) Direct transfer of alpha-synuclein from neuron to astroglia causes inflammatory responses in synucleinopathies. J Biol Chem 285:92629272. CrossRef Medline

Lee JS, Lee SJ (2016) Mechanism of anti-alpha-synuclein immunotherapy. J Mov Disord 9:14-19. CrossRef Medline

Lindström V, Fagerqvist T, Nordström E, Eriksson F, Lord A, Tucker S, Andersson J, Johannesson M, Schell H, Kahle PJ, Möller C, Gellerfors P, Bergström J, Lannfelt L, Ingelsson M (2014) Immunotherapy targeting alpha-synuclein protofibrils reduced pathology in (Thy-1)-h[A30P] alpha-synuclein mice. Neurobiol Dis 69:134-143. CrossRef Medline

Maldonado RA, LaMothe RA, Ferrari JD, Zhang AH, Rossi RJ, Kolte PN, Griset AP, O'Neil C, Altreuter DH, Browning E, Johnston L, Farokhzad OC, Langer R, Scott DW, von Andrian UH, Kishimoto TK (2015) Polymeric synthetic nanoparticles for the induction of antigen-specific immunological tolerance. Proc Natl Acad Sci U S A 112:E156-E165. CrossRef Medline

Mandler M, Valera E, Rockenstein E, Weninger H, Patrick C, Adame A, Santic R, Meindl S, Vigl B, Smrzka O, Schneeberger A, Mattner F, Masliah E (2014) Next-generation active immunization approach for synucleinopathies: implications for Parkinson's disease clinical trials. Acta Neuropathol 127:861-879. CrossRef Medline

Mandler M, Valera E, Rockenstein E, Mante M, Weninger H, Patrick C, Adame A, Schmidhuber S, Santic R, Schneeberger A, Schmidt W, Mattner F, Masliah E (2015) Active immunization against alpha-synuclein ameliorates the degenerative pathology and prevents demyelination in a model of multiple system atrophy. Mol Neurodegener 10:10. CrossRef Medline

Mannick JB, Del Giudice G, Lattanzi M, Valiante NM, Praestgaard J, Huang B, Lonetto MA, Maecker HT, Kovarik J, Carson S, Glass DJ, Klickstein LB (2014) mTOR inhibition improves immune function in the elderly. Sci Transl Med 6:268ra179. CrossRef Medline

Marxreiter F, Ettle B, May VE, Esmer H, Patrick C, Kragh CL, Klucken J, Winner B, Riess O, Winkler J, Masliah E, Nuber S (2013) Glial A30P alpha-synuclein pathology segregates neurogenesis from anxiety-related behavior in conditional transgenic mice. Neurobiol Dis 59:38-51. CrossRef Medline

Masliah E, Rockenstein E, Veinbergs I, Mallory M, Hashimoto M, Takeda A, Sagara Y, Sisk A, Mucke L (2000) Dopaminergic loss and inclusion body formation in alpha-synuclein mice: implications for neurodegenerative disorders. Science 287:1265-1269. CrossRef Medline

Masliah E, Rockenstein E, Adame A, Alford M, Crews L, Hashimoto M, Seubert P, Lee M, Goldstein J, Chilcote T, Games D, Schenk D (2005) Effects of alpha-synuclein immunization in a mouse model of Parkinson's disease. Neuron 46:857-868. CrossRef Medline

Masliah E, Rockenstein E, Mante M, Crews L, Spencer B, Adame A, Patrick C, Trejo M, Ubhi K, Rohn TT, Mueller-Steiner S, Seubert P, Barbour R, McConlogue L, Buttini M, Games D, Schenk D (2011) Passive immunization reduces behavioral and neuropathological deficits in an alphasynuclein transgenic model of Lewy body disease. PLoS One 6:e19338. CrossRef Medline

McKeith IG (2006) Consensus guidelines for the clinical and pathologic diagnosis of dementia with Lewy bodies (DLB): report of the Consortium on DLB International Workshop. J Alzheimers Dis 9:417-423. CrossRef Medline

Murphy DD, Reuter SM, Trojanowski JQ, Lee VM (2000) Synucleins are developmentally expressed, and $\alpha$-synuclein regulates the size of the presynaptic vesicular pool in primary hippocampal neurons. J Neurosci 20: 3214-3220. Medline

Overk CR, Cartier A, Shaked G, Rockenstein E, Ubhi K, Spencer B, Price DL, Patrick C, Desplats P, Masliah E (2014) Hippocampal neuronal cells that accumulate alpha-synuclein fragments are more vulnerable to Abeta oligomer toxicity via mGluR5-implications for dementia with Lewy bodies. Mol Neurodegener 9:18. CrossRef Medline

Reuter D, Sparwasser T, Hünig T, Schneider-Schaulies J (2012) Foxp3+ regulatory T cells control persistence of viral CNS infection. PLoS One 7:e33989. CrossRef Medline

Reynolds AD, Banerjee R, Liu J, Gendelman HE, Mosley RL (2007) Neuroprotective activities of $\mathrm{CD} 4+\mathrm{CD} 25+$ regulatory $\mathrm{T}$ cells in an animal model of Parkinson's disease. J Leukoc Biol 82:1083-1094. CrossRef Medline

Reynolds AD, Stone DK, Mosley RL, Gendelman HE (2009) Proteomic studies of nitrated alpha-synuclein microglia regulation by CD4+CD25+ T cells. J Proteome Res 8:3497-3511. CrossRef Medline

Reynolds AD, Stone DK, Hutter JA, Benner EJ, Mosley RL, Gendelman HE (2010) Regulatory T cells attenuate Th 17 cell-mediated nigrostriatal dopaminergic neurodegeneration in a model of Parkinson's disease. J Immunol 184:2261-2271. CrossRef Medline

Sarkar S, Rubinsztein DC (2008) Small molecule enhancers of autophagy for neurodegenerative diseases. Mol Biosyst 4:895-901. CrossRef Medline

Savica R, Grossardt BR, Bower JH, Boeve BF, Ahlskog JE, Rocca WA (2013) Incidence of dementia with Lewy bodies and Parkinson disease dementia. JAMA Neurol 70:1396-1402. CrossRef Medline

Shahaduzzaman M, Nash K, Hudson C, Sharif M, Grimmig B, Lin X, Bai G, Liu H, Ugen KE, Cao C, Bickford PC (2015) Anti-human alpha-synuclein $\mathrm{N}$-terminal peptide antibody protects against dopaminergic cell death and ameliorates behavioral deficits in an AAV-alpha-synuclein rat model of Parkinson's disease. PLoS One 10:e0116841. CrossRef Medline

Sigurdsson EM (2008) Immunotherapy targeting pathological tau protein in Alzheimer's disease and related tauopathies. J Alzheimers Dis 15:157168. CrossRef Medline

Specht CA, Lee CK, Huang H, Tipper DJ, Shen ZT, Lodge JK, Leszyk J, Ostroff GR, Levitz SM (2015) Protection against experimental cryptococcosis following vaccination with glucan particles containing cryptococcus alkaline extracts. MBio 6:e01905-15. CrossRef Medline

Spillantini MG, Goedert M (2000) The alpha-synucleinopathies: Parkinson's disease, dementia with Lewy bodies, and multiple system atrophy. Ann NY Acad Sci 920:16-27. CrossRef Medline

Suberbielle E, Djukic B, Evans M, Kim DH, Taneja P, Wang X, Finucane M, Knox J, Ho K, Devidze N, Masliah E, Mucke L (2015) DNA repair factor BRCA1 depletion occurs in Alzheimer brains and impairs cognitive function in mice. Nat Commun 6:8897. CrossRef Medline

Tofaris GK, Razzaq A, Ghetti B, Lilley KS, Spillantini MG (2003) Ubiquitination of alpha-synuclein in Lewy bodies is a pathological event not associated with impairment of proteasome function. J Biol Chem 278:44405-44411. CrossRef Medline

Tran HT, Chung CH, Iba M, Zhang B, Trojanowski JQ, Luk KC, Lee VM (2014) Alpha-synuclein immunotherapy blocks uptake and templated propagation of misfolded alpha-synuclein and neurodegeneration. Cell Rep 7:2054-2065. CrossRef Medline

Ubhi K, Masliah E (2013) Alzheimer's disease: recent advances and future perspectives. J Alzheimers Dis 33 [Suppl. 1]:S185-S194. CrossRef Medline

Valera E, Masliah E (2013) Immunotherapy for neurodegenerative diseases: focus on alpha-synucleinopathies. Pharmacol Ther 138:311-322. CrossRef Medline

Valera E, Masliah E (2016a) Combination therapies: the next logical step for the treatment of synucleinopathies? Mov Disord 31:225-234. CrossRef Medline

Valera E, Masliah E (2016b) Therapeutic approaches in Parkinson's disease and related disorders. J Neurochem 139 [Suppl. 1]:346-352. CrossRef Medline

Valera E, Spencer B, Masliah E (2016) Immunotherapeutic approaches targeting amyloid- $\beta, \alpha$-synuclein, and tau for the treatment of neurodegenerative disorders. Neurotherapeutics 13:179-189. CrossRef Medline

Wenning GK, Stefanova N, Jellinger KA, Poewe W, Schlossmacher MG (2008) Multiple system atrophy: a primary oligodendrogliopathy. Ann Neurol 64:239-246. CrossRef Medline

Wong YC, Krainc D (2017) alpha-Synuclein toxicity in neurodegeneration: mechanism and therapeutic strategies. Nat Med 23:1-13. CrossRef Medline

Wrasidlo W, Tsigelny IF, Price DL, Dutta G, Rockenstein E, Schwarz TC, Ledolter K, Bonhaus D, Paulino A, Eleuteri S, Skjevik ÅA, Kouznetsova VL, Spencer B, Desplats P, Gonzalez-Ruelas T, Trejo-Morales M, Overk CR, Winter S, Zhu C, Chesselet MF, et al (2016) A de novo compound targeting alpha-synuclein improves deficits in models of Parkinson's disease. Brain 139:3217-3236. CrossRef Medline

Xie J, Wang X, Proud CG (2016) mTOR inhibitors in cancer therapy. F1000Research 5:F1000 Faculty Rev-207. CrossRef Medline 